\title{
The Heredity of Senatorial Status in the Principate*
}

JOHN WEIS WEILER

\author{
ABSTRACT
}

Since Mommsen, it has been a tenet of Roman history that Augustus transformed the 'senatorial order' into a hereditary class, which encompassed senators, their children, grandchildren and great-grandchildren in the male line. This paper shows that the idea of a hereditary ordo senatorius is a myth without foundation in the evidence. Augustus and his successors conferred new rights and duties upon relatives of senators, but did not change their formal rank. Moreover, the new regulations applied not to three generations of descendants, but only to persons who stood under a senator's patria potestas during his lifetime. Emperors protected the honour and property of these filii familias of senators, in order to incentivise them to participate in politics and invest their wealth into munificence. The Supplementary Material available online gives all known early imperial holders of the title clarissimus vir in the province of Africa (Supplementary Appendix I), all known early imperial clarissimi iuuenes (Supplementary Appendix 2) and all known early imperial clarissimi pueri (Supplementary Appendix 3).

Keywords: Senate; marriage legislation; latus clauus; euergetism; clarissimi; patria potestas

It is conventionally thought that Augustus radically reformed the social structure of the Roman elite. He made senatorial rank hereditary. Henceforth, it is claimed, there was an important difference between the 'Senate' and the 'senatorial order'. Access to the 'Senate' was gained in the same ways as in the late Republic, through election to the lowest-ranking senatorial magistracy, the quaestorship. By contrast, the 'senatorial order' encompassed not merely the 600 or so former and current officeholders who were full members of the Senate, but also their wives, children, grandchildren and great-grandchildren in the male line. This view of the Roman elite as a hereditary class is enshrined in authoritative handbooks such as the Cambridge Ancient History, Der Neue Pauly, the Oxford Classical Dictionary or the Encyclopedia of Ancient

\footnotetext{
* This paper owes much to the generosity and insight of four old friends: Clifford Ando, Sarah Bühler, Myles Lavan and Sebastian Schmidt-Hofner. It has been much improved by audiences at the Seminar für Alte Geschichte in Tübingen and at the 2019 SCS meeting in Washington, DC. I was fortunate to profit from Peter Candy's legal advice and Beci Carver's flair for English style. Like so many JRS authors, I am indebted to the Editor, Christopher Kelly, and to the Journal's anonymous readers for their combination of rigour and big thinking; they crucially helped to fine-tune the argument and cut it down to a manageable size.
}

JRS I IO (2020), pp. 29-56. (C) The Author(s), 2020.

Published by Cambridge University Press on behalf of The Society for the Promotion of Roman Studies. This is an Open Access article, distributed under the terms of the Creative Commons Attribution licence (bttp:/l creativecommons.org/licenses/by/4.o/), which permits unrestricted re-use, distribution, and reproduction in any medium, provided the original work is properly cited.

doi:IO.IOI $7 /$ SOO 543582000 I 2 I 5 
History, ${ }^{\mathrm{I}}$ and has been endorsed by leading historians of the Senate such as Richard Talbert, Werner Eck and Géza Alföldy. ${ }^{2}$

Modern scholars derive this interpretation of the 'senatorial order' from the work of Theodor Mommsen. In the third volume of Römisches Staatsrecht, Mommsen identified six rights and duties that separated members of the 'senatorial order' from other citizens: they had the right to wear the toga with the broad purple stripe (latus clauus); they bore the status designation clarissimus; they participated in meetings of the Senate; they were prohibited from entering marriages with descendants of slaves; they were banned from engaging in certain forms of commerce; and they were exempt from the duty to finance acts of munificence in their cities of origin. But more important than the precise nature of these entitlements and obligations, was what they implied about the nature of the 'senatorial order' as a class. Mommsen explicitly likened the 'senatorial order' to a 'hereditary peerage'. On his reading, like the nobilities of the ancien régime, so the Roman senatorial elite was an 'aristocracy of birth', whose members enjoyed a set of rights and duties that separated them from other citizens. ${ }^{3}$

By describing the 'senatorial order' as a hereditary aristocracy, Mommsen offered later generations of scholars a powerful model to understand the legal structure of the Roman elite and the terminology employed in ancient texts. The strength of his explanatory framework emerges most strikingly from the fact that it was adopted by scholars who disagreed with Mommsen in their interpretation of individual items of evidence. In two separate papers, published in the I970s, André Chastagnol and Claude Nicolet noted that in some early imperial texts descendants of senators are described not as members of the ordo senatorius but as equestrians. ${ }^{4}$ Yet this discovery did not lead them to abandon the theory of a hereditary 'order'. In their view, if there was some 'ambiguity' in the ways in which relatives of senators were described, this was simply due to the fact that the full legal consequences of the reform took some time to be worked out. According to Chastagnol and Nicolet, such terminological 'confusion' only disappears when under Caligula the right to run for senatorial magistracies was restricted to members of the 'senatorial order'. ${ }^{5}$ But the two scholars did not doubt that Augustus transformed the ordo senatorius into a hereditary class. More specifically, Chastagnol and Nicolet argued the birth of the 'senatorial order' occurred in I 8 B.C.E. In this year, by increasing the minimum census for senators from 400,000 HS (the same as for equestrians) to $\mathrm{I}, 0 \circ 0,000 \mathrm{HS}$, and by prohibiting three generations of their descendants from marrying the offspring of slaves, Augustus brought into being a new notion of the ordo senatorius as a group which encompassed not only senators themselves but also their families. ${ }^{6}$

When Mommsen developed his theory, and when Chastagnol and Nicolet adopted and refined it, it was not unreasonable to think of the Roman elite as a hereditary group. Until the late twentieth century, it was widely believed that almost all sons of senators became senators too. Under such conditions, it was plausible to conceptualise the Roman elite as a class whose membership was hereditary not only in practice, but also in law. But in I985, Keith Hopkins and Graham Burton published a ground-breaking paper in which they demolished the long-standing belief that nearly all male descendants of officeholders participated in politics. Through an analysis of a sample of all consuls

1 Crook I967: I24; Talbert I996: 326; Galsterer 2000; Burton 20I 2: I347; Santangelo 20I2: 6I44.

2 Talbert I984: 39-47, esp. 39; Eck I998: 67-8; Alföldy 20 I I: I 50-62, esp. I 5 I.

3 Mommsen I 887: 466-75, quoting 466 and 467, 'erblichen Pairie' and 'Erbadel'.

4 Chastagnol I973; I992: 31-48; Nicolet I976: 32-8.

5 Quotations from Nicolet I976: 35, 'ambigüité' and Chastagnol I973: 585 ; I992: 36, 'confusion'. The theory that Caligula restricted the right to run for high office to laticlauii is convincingly challenged by Saller I982: 5 I-2 with n. 58 and Levick 1982 .

6 Chastagnol I973: 585-7; I992: 35-7; Nicolet I976: 38 . 
appointed between I4 and 235 C.E., Hopkins and Burton demonstrated that only a minority of sons of senators followed their fathers' careers. Most led a life of otium, free from the expenses and dangers of political life. ${ }^{7}$ Some rejected this radical conclusion out of hand. ${ }^{8}$ However, only two scholars put forward an alternative interpretation of the evidence on which Hopkins and Burton's argument was based. By recalculating how many sons of Antonine consuls became consuls too, Johannes Hahn and Paul Leunissen sought to demonstrate that the high turnover within the Senate was due to a decline in birth rates, not a lack of political participation. ${ }^{9}$ But as Burton pointed out in a reply to their paper, low fertility cannot explain why 'ordinary consuls', holders of the most prestigious magistracy, had more politically successful sons than the slightly less prominent 'suffect consuls'. Moreover, on any demographic model, if the great majority of sons of senators embarked on a political career, many more brothers would have held senior offices than are actually attested. ${ }^{\text {IO }}$ Hopkins and Burton's demonstration that most sons of senators did not run for high office is convincing.

But this insight creates a difficulty for the theory of a hereditary 'senatorial order'. If most children, grandchildren and great-grandchildren of a senator did not embark on a political career, but nevertheless inherited his rank, this would mean that in the first two centuries C.E. there were several times more politically inactive members of the 'order' than actual senators. Hopkins and Burton explicitly endorsed this hypothesis. They argued that the existence of the 'order' was one of the major reasons why so many descendants of senior officeholders withdrew from politics: 'In sum, the sons of senators inherited elements of their fathers' status, and that alone diminished their need to become full members of the senate in Rome.' ${ }^{\text {II }}$ But there is a problem with this argument. No such non-officeholding members of the 'senatorial order' are attested. Hopkins and Burton ascribed the lack of evidence to the bias of surviving sources: 'Those who did not achieve high positions were less likely to be honoured in a commemorative (as opposed to a tombstone) inscription.' ${ }^{\text {I2 }}$ Of course, as a general proposition, it is true that politically inactive persons are less well documented than senators. But the early Empire is one of the best attested periods in Mediterranean history. In their local communities, politically inactive descendants of senators would have been exceptionally influential figures. Surely some of them should be recorded - if not in honorific inscriptions, then at least in literature, legislation or (as Hopkins and Burton suggest in the quotation above) epitaphs. The complete lack of evidence for this group of persons suggests that something is wrong with the theory of senatorial heredity.

In this paper, I challenge the conventional view that Augustus transformed the 'senatorial order' into a hereditary class. I argue that that the Romans did not recognise any difference between senatus and ordo senatorius. As in the late Republic, so also in the early Empire, membership of the Senate depended on fulfilling a minimum census and securing election to a republican magistracy. This is not to deny that Augustus conferred some new rights and duties on relatives of officeholders; but the impact of these measures was much more limited than conventional interpretations suggest. Augustus neither created a hereditary 'order', which extended multiple generations after a senator's death, nor made rank hereditary. Rather, his reforms regulated the behaviour of a small group of young men and women who came under the patria potestas of a senator.

\footnotetext{
Hopkins and Burton I985.

8 Alföldy I986; Jacques I987.

9 Hahn and Leunissen I990.

10 Burton I995.

11 Hopkins and Burton I985, esp. I89-93, quoting I93.

12 Hopkins and Burton I985: I9I-2.
} 
I begin by re-examining the evidence on which the conventional view of senatorial heredity is based. I trace the ways in which descendants of senators are described in law (I), literature (II) and epigraphy (III), and explore the meaning of the new status designation clarissimus (IV). These different bodies of evidence show that senatorial rank did not become hereditary in the early Empire and that the Romans did not conceive of the 'senatorial order' as a group distinct from the 'Senate'. I then develop an alternative interpretation of early imperial regulations dealing with the relatives of senators. If these new laws are situated in the context of the Roman institution of patria potestas, it becomes clear that they affected not all children, grandchildren and great-grandchildren of an officeholder, but only those of his descendants who stood under his patria potestas during his lifetime $(\mathrm{V})$. The purpose of these regulations was to safeguard the honour of future members of the imperial elite and motivate them to embark on a senatorial career (VI). Augustus and his successors sought to increase political participation amongst officeholding families both for ideological reasons and because they depended on the wealth of large landowners to finance public services in Rome (VII).

\section{THE LEGAL CONSTITUTION OF THE SENATE}

I The formation of a 'senatorial order' is conventionally associated with the marriage legislation of Augustus. ${ }^{3}$ The following provision of the Lex Iulia de maritandis ordinibus, passed in I 8 в.C.E., allegedly transformed the Senate into a hereditary class:

The lex Julia provides that: 'A senator, his son or his grandson, or his great-grandson by his son shall not knowingly or fraudulently become betrothed to or marry a freedwoman, or a woman who is or has been an actress or whose father or mother are or have been actors. Nor shall the daughter of a senator, his granddaughter by his son, or great-granddaughter by his grandson become betrothed to or marry, knowingly or fraudulently become betrothed to or marry such a man. Nor shall any of these people knowingly or fraudulently become betrothed to or marry such a woman. ${ }^{\text {'4 }}$

This provision prohibited senators and their descendants for three generations in the male line from marrying men and women of servile descent. If challenged in court, children from such unions lost their rights of inheritance, and the fortunes of the deceased would be divided between the imperial fisc and the accusers. ${ }^{\text {I5 }}$ But does this mean that the law created a 'senatorial order' whose members enjoyed a clearly defined set of rights and duties? On the face of it, the excerpt does not warrant such a far-reaching interpretation. The Lex Julia does not contain the term ordo senatorius. Moreover, neither juristic commentaries nor historians offer any hint that the law changed the place of descendants of senators in official orders of precedence. ${ }^{16}$ The Lex Julia provides a surprisingly unstable foundation for the theory that Augustus transformed the Roman ruling class into a hereditary 'order'.

2 Another reform that supposedly contributed to the formation of a new ordo senatorius is reported by Suetonius in his biography of Augustus.

${ }_{13}$ See, for example, Chastagnol I973: 585-6; I992: 36; Nicolet I976: 38; Talbert I984: 39; Crook 1967: I 24; Eck I998: 67-8; Russell 20I9: 339-4I.

${ }_{14}$ Dig. 23.2.44 (trans. Watson I998: 2.205). Green et al. 1996 collect extant fragments.

15 Galinsky I98I; Wallace-Hadrill I98I; McGinn I99I; Mette-Dittmann I99I: I66-86 explore the impact of the marriage legislation.

16 See, most notably, Dig. I.9 and 23.2; Cass. Dio 54.I6 and 56.1.3-56.10; Suet., Aug. 34. 
In order to accustom descendants of senators more quickly to politics, he allowed them immediately after the toga uirilis to assume the broad purple stripe and to attend meetings of the Senate. And when they began military service, he gave them not merely a tribunate in a legion, but the command of an ala of cavalry as well; and to furnish all of them with military experience, he usually appointed two of these laticlauii to command each ala. ${ }^{17}$

According to Suetonius, upon reaching maturity, descendants of senators (liberis senatorum) received the status symbol of senators, the toga with the broad purple stripe (latus clauus). Henceforth, they served as junior officers in the imperial army (tribuni laticlauii), fulfilled various administrative functions in Rome (the so-called vigintiviri) and were allowed to attend meetings of the Senate as spectators. By creating this new preparatory stage for a senatorial career, Augustus tried to motivate them to participate in politics. ${ }^{\mathrm{I} 8}$

But again, this does not mean that the reform made senatorial rank hereditary. Other texts show that sons of equestrians or city councillors also frequently served as laticlauii. ${ }^{\text {I9 }}$ More importantly, laticlauii did not enjoy senatorial rank. This clearly emerges from several passages in Dio, which Nicolet has carefully examined. ${ }^{20}$ For example, when in 9 B.C.E. Augustus' stepson Drusus was buried, his body was carried by sons of senators and of equestrians: 'his body was carried to the Campus Martius by the equestrians, both those who belonged to the equestrian order proper, and those who were of senatorial descent'. ${ }^{2 I}$ Dio here clearly states that sons of senators were equestrians. This is confirmed in the discussion of cash subsidies given in 4 C.E. to prospective officeholders: Augustus supplied them with the senatorial minimum census, 'because many young men, both those who descended from senatorial families and the other equestrians, were impoverished through no fault of their own'.22 The same usage is found in Dio's description of Augustus' funerary cortège: 'Then the equestrians, both those who descended from the order and the others, ran around the pyre.'23 The 'others' mentioned by Dio can only be laticlauii: they descended from senators, but were members of the equestrian order. As mentioned in the introduction above, Nicolet and Chastagnol attempt to reconcile this evidence with the theory of a hereditary 'senatorial order' by suggesting that the status of descendants of senators remained 'ambiguous' in Augustus' and Tiberius' reigns. On this reading, only after Caligula would they be consistently classified as members of the 'order'. ${ }^{24}$ But this interpretation is unconvincing. Cassius Dio is not an Augustan, but a Severan author. The precise terminology employed in these passages, and the fact that he felt no need to explain it to his readers, clearly show that still in the early third century it was taken for granted that laticlauii were equestrians.

Upon closer inspection, then, the latus clauus creates further problems for the view that senatorial rank became hereditary in the early Empire. To be sure, the fact that descendants

17 Suet., Aug. 38.2 .

18 On the tribuni laticlauii, see Campbell I975: I8-I9; on the uigintiuiri, Steiner I973; Hillebrand 2007; Duncan-Jones 20I6: 8-2I.

19 The lists in Hillebrand 2007: 3 I-52 include many homines noui who served as uigintiuiri after the supposed formation of the 'order', such as Publius Petronius Turpilianus PIR ${ }^{2}$ P 3 I 5 (tresuir monetalis in the IOS B.C.E.); Marcus Salvius Otho PIR ${ }^{2} \mathrm{~S} \mathrm{I}_{2}$ (tresuir monetalis in 7 B.C.E.); Publius Sextius Lippinus Tarquitianus $P I R^{2} \mathrm{~S}$ 667 (quindecemuir stilitibus iudicanis around I3 C.E.). See also Section IV.2 below and Supplementary Appendix 2 in the online Supplementary Materials at https://doi.org/IO.IOI7/So07543582000I2I 5

20 Nicolet I976: $36-7$.

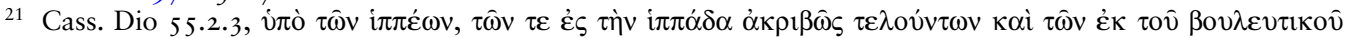

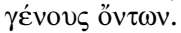

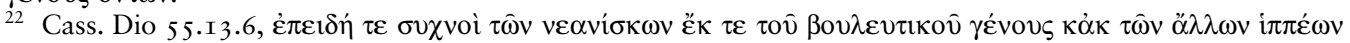

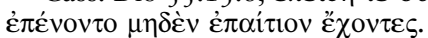

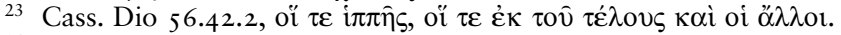

24 See n. 5 above. 
of senators automatically received the toga with the broad purple stripe, whereas others had to apply for it, made it easier for them to start a political career. In this way, as Augustus hoped, the creation of the laticlanii may indeed have increased political participation amongst officeholding families. But the reform did not change the formal rank of descendants of senators or make them members of a 'senatorial order'.

3 According to Cassius Dio (54.2.5), Augustus prohibited senators, their children and their descendants ( $\tau$ oi $\varsigma \dot{\varepsilon} \gamma \gamma$ óvors), 'at least in so as far as they belonged to the equestrian order'

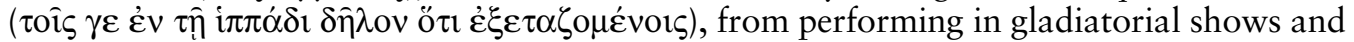
other public entertainments. In other words, only those relatives of senators who fulfilled the equestrian minimum census of $400,000 \mathrm{HS}$ were subjected to the regulation. Under his successor Tiberius, this prohibition was extended to include all equestrians and three generations of their cognatic descendants and ancestors. ${ }^{25}$ The fact that Dio again classifies descendants of senators as equestrians further undermines the theory of a hereditary 'order'.

4 Two final regulations on relatives of senators are only attested in excerpts of the Pauli Sententiae, a legal handbook compiled sometime in the third century. ${ }^{26}$ According to a fragment that has survived in a manuscript in Leiden, 'senators and progenitors under whose potestas they stand' were prohibited from engaging in tax-farming, merchant shipping or commercial horse breeding. ${ }^{27}$ This was a restatement of an ancient rule. According to Livy, the Lex Claudia, passed in 2 I 8 B.C.E., prohibited 'senators and whoever had a senator as father' from owning merchant ships. ${ }^{28}$ There are two differences between Livy and the Pauli Sententiae. First, according to the latter text, the law outlawed investments not only in trade, but also in tax-farming and horse-breeding. It seems that sometime in the early Empire the scope of the Lex Claudia was expanded. Perhaps Hadrian had modified the law? Dio relates that this emperor prohibited senators from investing in tax-farming, either directly or through intermediaries. ${ }^{29}$ Second, the statement in Pauli Sententiae affects a different group of persons than the earlier law. While the original Lex Claudia regulated the economic activity of senators and the persons under their patria potestas, the later text discusses senators and their own patres familias: 'the progenitors (parentes) under whose potestas they stand'. But this discrepancy does not mean that the law had changed. It is important to keep in mind that the Pauli Sententiae was not a lawcode, but a collection of juristic opinions. By suggesting that prohibitions on the fortunes of senators should also apply to their pater familias, the author expressed his personal view on how the Lex Claudia should be interpreted. His interpretation makes sense, since the pater familias was the legal owner of all assets managed by persons who stood under his patria potestas. ${ }^{30}$ Perhaps the discussion was inspired by a specific case, in which a senator's father had invested in one of the prohibited enterprises. In any case, the Lex Claudia did not change the formal rank of senators or imply that their relatives had become members of a hereditary 'order'.

\footnotetext{
25 See EAOR III 2 = Stelluti I997: no. Iooa with the commentaries and discussions by Levick I983; Stelluti I997: I.I73-6; Baltrusch I989: 195-206.

26 On this text, see Levy I930; Liebs I989; Ruggiero 2017.

27 Paulus, Sent., Frag. Leid. 3, 'Senatores parentesue eorum, in quorum potestate sunt, uectigalia publica conducere, nauem in quaestum habere, equosue curules praebendos suscipere prohibentur' (for the text, see Archi et al. 1956).

28 Livy 2 I.63.3-4, quoting $\mathbb{S}$, 'ne quis senator cuiue senator pater fuisset maritimam nauem, quae plus quam trecentarum amphorarum esset, haberet'. Baltrusch 1989: 30-40 offers a detailed discussion of the republican law with bibliography.

29 Cass. Dio 69.16.2.

30 On patria potestas of senators, see further Section V below.
} 
5 Another fragment of the same handbook, preserved in the Digest, states that not only senators themselves, but also their children, grandchildren and great-grandchildren in the male line could not be forced to pay for compulsory public functions in their hometowns:

Senators and their sons and daughters, whenever born, and equally their grandsons <and granddaughters $>$, great-grandsons and great-granddaughters by the son are removed from their fiscal domicile (origo), even if they retain municipal dignity. ${ }^{3 I}$

The author of the Pauli Sententiae asserts that even those descendants of senators who were city councillors were not subject to local liturgies: they 'are removed from their fiscal domicile, even if they retain municipal dignity', as the text puts it. Again, the opinion was probably inspired by a specific case; strictly speaking, it was superfluous to add that the immunity affected children of senators 'whenever born' ('quoquo tempore nati nataeue') and 'even if they retain municipal dignity' ('licet municipalem retineant dignitatem'). Presumably, a senator wished to know whether he was liable to pay for the public functions of a son who had been elected into a local city council and who had been born before his own promotion to the imperial elite. The jurist affirmed that the immunity from munificence in cities outside Rome also applied in this borderline situation. But irrespective of why the statement was included in the Pauli Sententiae, what matters for our purposes is that non-officeholding relatives of senators are classified as persons 'of municipal dignity', not as members of the 'senatorial order'.

To sum up, an initial review of the legal evidence suggests that the theory of a hereditary 'senatorial order' rests on shakier ground than is conventionally realised. While it is true that Augustus regulated the lives of descendants of senators in new ways, there is no sign that their formal rank changed. On the contrary, all evidence considered so far suggests that they were classified not as members of the 'senatorial order', but as equestrians or persons of 'municipal dignity'.

\section{SENATE AND SENATORIAL ORDER IN LITERATURE}

Legal texts give no indication that the status of relatives of senators changed in the early Empire. Does early imperial literature show traces of a hereditary senatorial class? In the Republic, the term ordo senatorius referred to the same social group as the word senatus. ${ }^{32}$ The only difference in usage was that the ordo senatorius highlighted the 'rank' (ordo) of a senator, ${ }^{33}$ while the word senatus evoked more immediately the institution of which he was a member. ${ }^{34}$ If Augustus transformed the Roman elite into a hereditary class, we would expect that the semantics of the word changed accordingly. The expression 'senatorial order' (ordo senatorius) should refer no longer only to senators themselves, but also to their children, grandchildren and great-grandchildren in the male line. This is what is normally assumed. According to Chastagnol and Nicolet, though traces of the old usage survived until the reign of Caligula, the term began to be used in 'un nouveau sens' from the reign of Augustus. ${ }^{35}$ Hopkins and Burton concur:

\footnotetext{
31 Dig. 50.I.22.5, with Mommsen's emendation, 'Senatores et eorum filii filiaeque quoquo tempore nati nataeue, itemque nepotes <et neptes>, pronepotes et proneptes ex filio origini eximuntur, licet municipalem retineant dignitatem.'

32 As shown by Nicolet I976: 33-4 and accepted by Chastagnol I973: 584-5; I992: 34-5.

33 OLD s.v. ordo 4 and TLL 9.2.96I. Cohen I975; Nicolet I984a; Rilinger I99I explore Roman conceptions of ordo.

34 OLD s.v. senatus I.

35 Chastagnol I973: 585-93, quoting 585; I992: 37-40, quoting 37; cf. Nicolet I976: $35-8$, esp. 35 n. 37 : 'Sous l'Empire, ordo senatorius désigne clairement les sénateurs et leurs familles (Suet., Calig. I7.3), et donc la qualité
} 
'under the emperors, the term came to include senators' immediate family and descendants'. ${ }^{36}$ However, is it actually true that in the Principate the expression 'senatorial order' referred not only to senatorial officeholders, but also to their relatives? Surprisingly, this assertion has never been systematically tested. I have collected all instances in which the expression ordo senatorius is employed in the Latin literature of the Principate. From the time of Augustus until the third century, it appears thirty-four times. The occurrences may be divided broadly into three groups.

Firstly, in eight cases, the expression is employed to describe promotions into the 'senatorial order'. In all these examples, it can unambiguously be determined that members of the 'order' are synonymous with the around 600 officeholders who were members of the 'Senate'. For example, when Valerius Maximus records that a man has been 'adlected into the senatorial order', this can only mean that he has become a senator in the full sense of the word - adlectio is the legal term for the formal process of admission into the Senate. ${ }^{37}$ Throughout the period from the time of Augustus until the third century, there is no change from republican usage - the term ordo senatorius refers to the same group of persons as the words senatus or senatores. ${ }^{38}$ Secondly, in another six instances, the 'senatorial order' is mentioned in discussions of a loss of status. Men were 'expelled from the senatorial order', 'lost' or 'gave up their rank'. Again, this means not merely that they were demoted from a diffuse 'senatorial class', but concretely that they lost their seat in the Senate. For in all cases, it can be shown that the disgraced persons were current or former officeholders. Again, no shift in the semantics of the word is discernible. The meaning of the word ordo also does not change over time, as Nicolet and Chastagnol assume - the evidence mainly consists of texts written in the late first and second centuries, long after the alleged reform of the 'senatorial order' carried out by Caligula. ${ }^{39}$

des fils de sénateurs, même lorsqu'ils n'ont pas encore exercé les honneurs.' ('Under the Empire, ordo senatorius clearly denotes senators and their families (Suet., Calig. I7.3) and thus the condition of sons of senators, even if they have not yet held office.') On the 'ex senatorio ordine aurigantibus' in Suet., Calig. I 8.3, see n. 42 below.

36 Hopkins and Burton I985: I93.

37 Val. Max. 2.2.I, 'in ordinem senatorium allectum'. Chastagnol I992: 97-I 20 and Millar I992: 293-7 trace the development of adlectio in the early Empire.

38 When Tacitus in Hist. 3.52.3 refers to 'Plotius Grypus, who had recently been adlected into senatorial order ('nuper a Vespasiano in senatorium ordinem adscitum') and put in charge of a legion', he must mean an adlectio inter quaestorios. A legionary command was the first office senators customarily accepted after their quaestorship. Suetonius' discussion of the social origins of Vitellius' family in Vit. I.3 - 'who returned to the city and into the senatorial order' ('repetisse urbem atque ordinem senatorium') - concludes a section on their political achievements. Similarly, in Suetonius' biographies of grammarians and in the commentary of Pomponius Porphyrio on Horace, membership in the ordo is explicitly linked to a political career: Suet., Gram. et rhet. 25.7 , 'in ordinem senatorium atque ad summos honores processerint' ('they advanced to senatorial rank and to the highest honours') and Commentum in Horatium ad Sermones 1.6.34-5 (ed. A. Holder, Pfaffenhofen, I894, 263.I3-I4), 'qui se inserit senatorio ordini et rem publicam administrare cupit' ('who inserts himself into the senatorial order and desires to govern the state'). Finally, Tac., Hist. 2.86.I 'senatorium ordinem reciperauerat' ('he had recovered senatorial rank') refers to Antonius Primus' restoration to full senatorial membership and Tac., Hist. 2.82.2 'plerosque senatorii ordinis honore percoluit' ('he adorned many with the honour of senatorial rank') alludes to Vespasian's expansion of the Senate.

39 Suet., Iul. 43.I, 'repetundarum conuictos etiam ordine senatorio mouit' ('he also removed those who had been convicted of extortion from the Senate'), discussing former governors. Tac., Hist. 4.44.2, 'Octauium Sagittam et Antistium Sosianum senatorii ordinis egressos exilium in easdem insulas redegit' ('after they had left the senatorial order, he exiled Octavius Sagitta and Antistius Sosianus to those same islands'): Sagitta appears in Ann. I 3.4O. I as tribune of the plebs and Sosianus in Ann. I4.48-9 as praetor. Tac., Ann. 6.48.4, 'Carsidius Sacerdos praetorius ut in insulam deportaretur, Pontius Fregellanus amitteret ordinem senatorium' ('to deport the ex-praetor Carsidius Sacerdos to an island and to strip Pontius Fregellanus of senatorial rank'): the persons in question are a former praetor and a consul suffectus, see $P I R^{2} \mathrm{C} 45 \mathrm{I}$ and P 800 . Tac., Ann. I 2.4.3, 'at Silanus, insidiarum nescius ac forte eo anno praetor, repente per edictum Vitellii ordine senatorio mouetur quamquam lecto pridem senatu lustroque condito' ('But Silanus, unaware of the plot and - as it turned out - praetor in that year, was suddenly expelled from the Senate through an edict of Vitellius, despite the fact that the review of the Senate 
Thirdly, there are eighteen examples in which the word was used to distinguish the rank of senators from other status groups. These passages may be divided into two sub-groups. In six cases, texts refer to the status of an individual member of the 'senatorial order'. In four of these six, other evidence enables us securely to identify the person as a senatorial officeholder. ${ }^{40}$ In the remaining two examples, the uiri ordinis senatorii in question are otherwise unattested. However, they were clearly highly informed political operators: Seneca mentions a Rufus, uir ordinis senatorii, who told a joke about the emperor Caligula's sacrificial practice, and Tacitus calls two participants of the Pisonian conspiracy uiri ordinis senatorii. The fact that they appear in the context of high politics strongly suggests that they were full members of the Senate. ${ }^{4 \mathrm{I}}$ In the other twelve cases, the word ordo senatorius is employed to differentiate groups of men of 'senatorial rank' from other social strata. ${ }^{42}$ Also in these examples, it can almost always be shown that the authors had in mind full members of the Senate, and not their relatives. For example, in his discussion of the aftermath of the trial against Libo, Tacitus writes that 'the estates of this prominent senator were divided amongst his accusers' and that those amongst them 'who were of senatorial rank' ('qui senatorii ordinis erant') were in addition honoured with praetorships. The reference is to the group of senior

had already been carried out and the census concluded'). Tac., Ann. I2.52.3, 'laudati dehinc oratione principis, qui ob angustias familiares ordine senatorio sponte cederent, motique qui remanendo impudentiam paupertati adicerent' ('those who voluntarily resigned senatorial rank were praised in the emperor's speech, those who by staying added infamy to poverty were expelled'): about a speech in the Senate. See also Val. Max. 2.9.3, '... perinde ac malo exemplo luxuriosum in ordine senatorio retentum non esse' ('because his extravagance set a bad example he was not kept in the senatorial order'): an exemplum from the Republic, in which the supposed ordo did not yet exist.

40 Known officeholders: Tac., Agr. 4.I, 'pater illi Iulius Graecinus senatorii ordinis' (tribune of the plebs and praetor: see $A E$ I946. $94=$ CIL 6.4 IO69); Val. Max. 5.8.5, 'A. Fuluius uir senatorii ordinis' (the same person is called a senator in Sall., Cat. 39.5); Vell. Pat. 2.69.I, 'quo tempore Capito, patruus meus, uir ordinis senatorii, Agrippae subscripsit in C. Cassium' ('at that time my uncle Capito, a man of senatorial rank, signed Agrippa's indictment of Gaius Cassius'): the prosecution of Caesar's murderers took place many years before the alleged formation of the senatorius ordo. Tac., Hist. 4.68.2 reports that Arrecinus Clemens, 'quamquam senatorii ordinis' ('despite being of senatorial rank'), was appointed praetorian prefect by Vespasian. $A E$ I $947.40=$ Suppl It I.4 shows that he had previously been praetor and later became consul twice. On his career, see further Eck I999.

41 Sen., Ben. 3.27.I, 'Rufus, uir ordinis senatorii' ('Rufus, a man of senatorial rank') and Tac., Ann. I 5.49.4, 'Flauius Scaeuinus et Afranius Quintianus, uterque senatorii ordinis' ('Flavius Scaevinus and Aranius Quintianus, both of senatorial rank').

42 Livy 3 5.6.5, 'ut duos legatos ex ordine senatorio mitteret ad L. Cornelium consulem' ('that he would send two envoys of senatorial rank to the consul Lucius Cornelius') and 43.2.3, 'ut in singulos a quibus Hispani pecunias repeterent quinos recuperatores ex ordine senatorio daret' ('that for each man from whom the Hispani demanded compensation, he would appoint five judges of senatorial rank') both clearly refer to senatorial officeholders; Suet., Aug. 35.I, 'decem ualentissimis senatorii ordinis amicis sellam suam circumstantibus' ('ten of his strongest friends of senatorial rank surrounding his chair'): the reference is to the period before the alleged formation of the 'senatorial order'; Val. Max. 5.2.6, 'Q. Terentius Culleo praetoria familia natus et inter paucos senatorii ordinis splendidus' ('Quintus Terentius Culleo from a praetorian family and as eminent as few other members of the senatorial order'): on any interpretation, 'inter paucos senatorii ordinis splendidus' must refer to a senior officeholder; Suet., Tib. 23.I, 'inlatum deinde Augusti testamentum, non admissis signatoribus nisi senatorii ordinis, ceteris extra curiam signa agnoscentibus, recitauit per libertum' ('After he had Augustus' testament brought in, and only men of senatorial rank were let in to sign, the others acknowledging their seals outside the senate-house, he had it read out by a freedman'): admission to the senate-house would seem to exclude minors or women. The 'cuneos equestris ac senatorii ordinis' upon which Domitian according to Suet., Dom. 4.5 showered gifts clearly are the same groups as the 'senatui equitique' mentioned earlier in the same sentence. According to Suet., Calig. I 8.3, Caligula organised a series of races in which 'all charioteers were of senatorial rank' ('nisi ex senatorio ordine aurigantibus'); pace Nicolet (n. 35 above), there is no evidence they included women or children. Pseudo-Cicero, Declamatio in L. Sergium Catilinam III, 'interitum crudelissimum senatorii ordinis' ('the most cruel extinction of the senatorial order') refers to Catiline's supposed plan to exterminate all senators. Pseudo-Cicero, Declamatio in L. Sergium Catilinam II6, 'pro defensa consulum uita seruataque senatorii ordinis dignitate' ('for having defended the lives of the consuls and preserved the dignity of the senatorial order') denotes the Senate as an institution. 
officeholders who brought Libo to trial, several of whom had earlier been mentioned by the historian. If Tacitus describes them as qui senatorii ordinis erant and not as senatores, this is not because they were only members of a senatorial class but not of the Senate. Rather, ordo is the better word because what the historian wishes to emphasise here is their 'senatorial rank', not their participation in the institution of the 'Senate': Tacitus contrasts them with other accusers who were of equestrian status - unlike senators, those men were rewarded for their services solely with financial benefits but did not receive public offices. ${ }^{43}$

Two passages feature a subtle change in the ways the word is used. Both come from Tacitus. In Book I 3 of the Annals, the historian tells the story of one of Nero's drinking tours through Rome, during which he picked a fist-fight with 'Iulius Montanus, of senatorial rank, but who had not yet held office'. ${ }^{44}$ The terminology is a departure from previous practice. In the late Republic, membership of the Senate was obtained by holding the quaestorship. There could be no senator 'who had not yet held office'. The fact that Montanus could be counted a member of the ordo before he had obtained the quaestorship was the product of a reform introduced by Augustus. As noted in Section I.2 above, the first emperor gave adult sons of senators who planned to embark on a political career the right to wear the traditional dress of senators, the toga with the broad purple stripe (latus clauus). Montanus was such a laticlauius, who was allowed to attend meetings of the Senate and served as military tribune in the imperial army, but had not yet held office and thus was not yet a full senator. ${ }^{45}$ Significantly, when Suetonius discusses the same incident, he calls Montanus quidam laticlauius. ${ }^{46}$ Tacitus observes the same usage in a passage from the Histories in which he relates the story of Vespasian's general Cornelius Fuscus. Fuscus was born into a senatorial family but then abandoned an officeholding career. ${ }^{47}$ Tacitus describes his withdrawal from politics in a sartorial metaphor: 'out of a desire for a leisured life, Fuscus in his early youth took off (the symbols of) senatorial rank' ${ }^{48}$ It is possible that by the time he gave up his political ambitions, Fuscus had already secured election to the quaestorship. More likely, he was a laticlauius, who was expected to undertake a political career, but not yet a formal member of the Senate. This interpretation is supported by Tacitus' language: by his 'taking off' (exuerat) the symbols of senatorial status, the historian refers to his rejection of the toga with the broad purple stripe. As in the case of Montanus, so also in the passage about Fuscus, Tacitus seems to count laticlawii as men of 'senatorial rank'. For Chastagnol, the discussion of Montanus' rank in the Annals is a key piece of evidence for his view of the consolidation of a hereditary 'senatorial order' in the reign of Caligula. ${ }^{49}$ But it is doubtful whether Tacitus in this episode (and in the parallel passage on Fuscus) intended the term ordo senatorius to be understood in a technical sense. As detailed above, in other texts laticlauii are classified as members of the equestrian order. More likely, this unparalleled usage was a deliberate stylistic choice. Tacitus usually avoids technical language, or employs it in idiosyncratic ways; in the words of Tony Woodman, 'the use of apparently technical language in a non-technical way is typically Tacitean'. ${ }^{\circ}$ As Ronald Syme notes, the term latus clauus was amongst the expressions

\footnotetext{
43 Tac., Ann. 3.2.I, 'Bona inter accusatores diuiduntur, et praeturae extra ordinem datae iis qui senatorii ordinis erant.'

44 Tac., Ann. I3.25.2, 'Iuliusque Montanus senatorii ordinis, sed qui nondum honorem capessisset.'

45 On his career, see $P I R^{2}$ I 435 and CIL I I.3884 = Dessau, ILS 978.

46 Suet., Ner. 26.2, 'a quodam laticlauio, cuius uxorem adtrectauerat, prope ad necem caesus' ('he was almost beaten to death by a laticlauius, whose wife he had assaulted').

47 PIR ${ }^{2}$ F I365.

48 Tac., Hist. 2.86.3, 'prima iuuenta quietis cupidine senatorium ordinem exuerat'.

49 See Chastagnol I973: 603-4; I992: 65-6.

50 Woodman 20I7: I36; see also Ash 2018: I 86, 'T. often avoids technical language in ostentatious ways' and the index in Woodman and Martin I996: 503, s.v. 'technical or official language slightly distorted'.
} 
which Tacitus deliberately shunned in his historical works. By paradoxically depicting laticlauii as senators who had not held office, he avoided technical terminology inappropriate for the genre of historiography. ${ }^{\mathrm{I}}$

The two passages in the Annals in which laticlauii are depicted as men of senatorial rank are the only evidence that the Latin terminology of status changed in the early Empire. There is no instance in which the word ordo senatorius refers to more distant descendants of senators, or to their wives. This is remarkable. While the effects of Augustus' measure to permit a select group of elite males to participate in senatorial meetings can be traced, what should have been the most important aspect of his reforms the formation of a hereditary senatorial class - does not seem to have left any traces in extant literature. A second foundation of the theory of senatorial heredity turns out to be hollow.

\section{INSCRIBING SENATORIAL RANK}

Early imperial law and literature thus show no traces of a hereditary 'senatorial order'. Are inscriptions more forthcoming? The time from Augustus until the Severan period is the 'golden age' of Latin epigraphy. Thousands of inscriptions discovered across the Mediterranean and western Europe have yielded detailed information about the social, economic, cultural and religious history of the Roman Empire. While the gaps in our evidence remain considerable, we are better informed about the early imperial elite than about most other pre-modern governing classes. ${ }^{52}$ It is true that stone inscriptions were usually put up to honour successful officeholders - those who refused to engage in a political career are thus usually not epigraphically attested. As a result, extant texts rarely deal with those relatives of senators who withdrew from public life. ${ }^{53}$ Still, some scattered evidence enables us to identify the formal status of politically inactive descendants of senators. Strikingly, whenever such persons are epigraphically attested, they are described not as members of the 'senatorial order', but as equestrians.

In the senatus consultum de Pisone patre, Gnaeus Piso, an adult son of the accused, who had accompanied his father to Syria, but who had not yet held a senatorial magistracy, is explicitly described as a person 'who was not yet member of the senatorial order' ('qui ordinis senatori nondum esset'). ${ }^{54}$ A series of inscriptions from Sparta, whose prosopography has been carefully analysed by Anthony Spawforth, gives the names and achievements of the two sons of Tiberius Claudius Brasidas, one of only two Laconians who ever became senators in Rome. The texts date from the Severan period. They attest to the priesthoods of the imperial cult held by the descendants of the senator and to their intimate relations with Roman governors and high officials. Significantly, however, in all these inscriptions, Brasidas' sons never carry the status designations of senators but indeterminate epithets such as 'most worthy' ( $\dot{\alpha} \xi 10 \lambda \sigma \gamma \omega \dot{\omega} \alpha \tau \circ \varsigma)$ or 'the all-first' $(\pi \alpha \nu \tau \dot{\alpha} \pi \rho \omega \tau \varsigma \varsigma)$. In line with the traditional interpretation, Spawforth nevertheless assumes that they were members of the ordo senatorius: 'both, as the sons of a senator, would have inherited senatorial rank'. But the consistent lack of senatorial titulatures in all inscriptions makes it hard to believe that this was in fact the case. ${ }^{55}$ From the province of Asia, another three high priests of the imperial cult are known who were

\footnotetext{
51 Syme I958: I.460 n. 2. Christol 200I shows that the word laticlauius was technical and extremely rare.

52 The edited volumes by Panciera I 982 and by Caldelli and Gregori 20I4 survey the contribution made by epigraphy to senatorial prosopography.

53 Eck 2007 highlights the disjunction between patterns of attestation and social reality.

54 See 1l. 20-I, with the commentary by Eck et al. I996: I44.

55 See Spawforth I98 5: 227-38, esp. 237-8, quoting 237. Spartiacus is attested in IG 5.I 323 and 525; Brasidas in $I G$ 5.I 302, 3I2, 332 and $50 \mathrm{I}$. All these texts record provincial priesthoods, but no senatorial titles.
} 
sons of senators. They never carry senatorial status designations either. ${ }^{56}$ It is also notable that as leaders of the provincial imperial cult, all these men must have invested substantial sums in munificence. Yet they did not take advantage of the immunity from local liturgies allegedly enjoyed by descendants of senators (discussed in Section I.5 above).

This assessment that senatorial status was not hereditary is confirmed by the usage of the word 'senatorial order' in Latin inscriptions. All men epigraphically attested as members of the 'order' were active in politics, not mere relatives of senators. In most texts, promotion into the 'order' is explicitly associated with formal adlectio to the Senate, at the rank of a magistracy defined by the emperor. ${ }^{57}$ However, there was some ambiguity surrounding the status of laticlanii. In four inscriptions, put up in the reigns of Trajan and Hadrian, the conferral by the emperor of the toga with the broad purple stripe is depicted as admission into the 'order'; only later did the persons in question achieve the entry magistracy for the Senate, the quaestorship. ${ }^{58}$ This usage is reminiscent of Tacitus' description of the status of Montanus and Fuscus. ${ }^{59}$ The fact that laticlanii were sometimes depicted as men of 'senatorial rank' reflects the problems of classification posed by this in-between group, whose members wore senatorial dress and participated as spectators in senatorial meetings, but had no voting rights in the assembly. It may be no coincidence that both Tacitus' historical works and these inscriptions were produced in the early second century C.E. As will be explored in the next section, there are other signs that in this period the status of descendants of senators became an urgent question, in ways in which it had not been before. But for present purposes, another fact is more noteworthy. In all of imperial epigraphy, there is no single text in which a politically inactive descendant of a senator or his wife is described as member of the 'order'. Strikingly, the supposed extension of the senatorial class left no trace in inscriptions.

A third pillar of the theory of senatorial heredity has collapsed. The combined evidence from imperial law, literature and epigraphy makes it hard to sustain the conventional view that senators transmitted their rank to their children, grandchildren and great-grandchildren in the male line. But before we explore the implications of this finding, it is necessary to look at a fourth and final body of evidence that is usually thought to support the traditional theory.

\section{A NEW TERMINOLOGY OF STATUS}

From the Antonine period, in a rising number of inscriptions, senators and their relatives bear the status designation clarissimus, 'most distinguished'. Senators were called uir

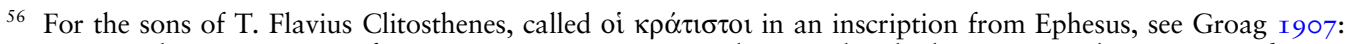
285-6. For the younger son of Cn. Pompeius Hermippus, who served as high priest in Ephesus, see IEph 7IO. All these cases are discussed by Halfmann I982: 622 .

57 See, for example, CIL 2.98I = HEp 9.534, 'tribunicio allecto in amplissimum ordinem'; CIL 6.4 I I $30=$ Dessau, $I L S$ I 452, '[adlecto in amplissimum] ordinem inter praetorios'; CIL I 2.2453, '[omnibus honoribus] Viennae [functo a]dlecto in amplissimum ordinem inter quaestorios aedili curuli praetori legato prouinc(iae) Asiae' ('after having performed all magistracies in Vienna, adlected into the highest order amongst the ex-quaestors, curule aedile, praetor, legate of the province of Asia') ; CIL I0.6520, 'adlecti in ordine senatorio a $\mathrm{Ti}($ berio) Claudio Caes(are) Aug(usto) Germanico cens(ore) inter tribunicios' ('adlected into the senatorial order amongst ex-tribunes by Tiberius Claudius Caesar Augustus Germanicus, censor').

58 See CIL I 2.4354 = Dessau, ILS I064, 'omnib(us) honoribus in colonia sua funct(o) adlecto in amplissimum ordinem ab Imp(eratore) Caes(are) Hadriano Aug(usto) IIIIIIuir(o) equitum Romanor(um) curioni quaestori urbano trib(uno)' ('after having performed all magistracies in his colonia adlected into the highest order by the emperor Caesar Hadrianus Augustus, seuir of the equites Romani, priest, quaestor urbanus, tribune'); CIL I3.I802 'adlecto ab diuo Traian(o) Parthic(o) in splendidissim(um) ordin(em) q(uaestori) ur[b]an(o)' ('admitted by the divine Trajan Parthicus into the most brilliant order, quaestor urbanus'); and CIL I3.I808 $=$ Dessau, ILS I454, 'adlecto annorum quattuor in amplissimum ordinem'. These cases are excellently discussed by Chastagnol I992: I08-9 and II 5-I6.

59 See Section II and nn. 46-7 above.
} 
clarissimus, their wives clarissima femina, their adult sons clarissimus iunenis, infant sons clarissimus puer and infant daughters clarissima puella. ${ }^{60}$ The Greek translations $\lambda \alpha \mu \pi \rho$ ó $\alpha \tau \sigma \varsigma \zeta$ and $\lambda \alpha \mu \pi \rho \tau^{\prime} \alpha \tau \eta$, employed without accompanying nouns, appear around the same time. ${ }^{6 I}$ The spread of status designations that were employed by both senators and their relatives might seem proof that senatorial rank had now finally become hereditary. But yet again, a closer look at the evidence problematises this interpretation.

\section{Clarissimus Vir}

Let us begin with the status designation clarissimus uir. This title began to appear in the reign of Hadrian. Chastagnol suggests that it always denotes actual senators: 'Ce titre de clarissimus uir s'applique seulement aux sénateurs effectifs. ${ }^{62}$ By contrast, Hopkins and Burton argue (with some hesitation, but in keeping with their theory that senators transmitted their rank to politically inactive descendants) that some non-officeholders also laid claim to this title: 'some of those recorded in tombstone inscriptions as having senatorial status ... may not have been full members of the senate but rather politically inactive members of the senatorial order. ${ }^{63}$

Several thousand inscriptions containing the title uir clarissimus are currently known. A complete analysis of this vast corpus of texts is impossible. As a case study, I have collected all clarissimi uiri attested in Africa Proconsularis from the Antonine period until the accession of Diocletian. Sixty-four of seventy-two holders of this title can be shown to have exercised senatorial offices. Another six served as curator, an imperially appointed municipal administrator, or as patronus, patron of a city. ${ }^{64}$ As Graham Burton and François Jacques have shown, until the Tetrarchy these functions were almost always fulfilled by senators or senior equestrian officeholders. ${ }^{65}$ For the remaining two clarissimi uiri, we have no information on their public lives. ${ }^{66}$ Of course, it is theoretically possible that they were politically inactive descendants of senators. But this is unlikely. If senators automatically transmitted their rank to their children, grandchildren and great-grandchildren, non-officeholding clarissimi uiri would have far outnumbered actual senators. Yet no single such person can securely be identified. Moreover, as will be recalled from the previous section, when politically inactive descendants of senators are attested in other regions of the Empire, they never carry senatorial titles. ${ }^{67}$ Chastagnol's view that the title uir clarissimus denoted full members of the Senate is surely correct.

\section{Clarissimus Iunenis}

The same scholar maintains that the status designation clarissimus iumenis referred to laticlauii, young men who fulfilled some of the preparatory functions for a senatorial career, either as uigintiuiri in Rome or tribuni laticlauii in the provinces. ${ }^{68} \mathrm{~A}$ full review

\footnotetext{
60 Hirschfeld I90I remains the pioneering study of status designations. Corbier 2006 and Heil 20 I 5 offer more recent overviews.

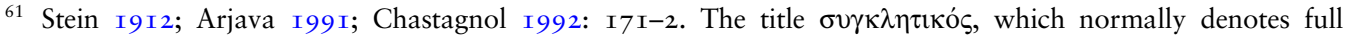
members of the Senate, is rarer and was almost exclusively employed in Asia Minor: see, for example, IGR 3.I73 (II4 C.E.); IGR 4.I687 (after II4 C.E.); Milet 6.3 II35 (Antonine); IEph IIO5 (I67-I69 C.E.). On

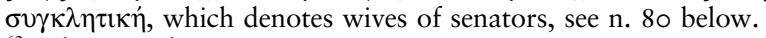

62 Chastagnol I992: I7I-2, quoting I7I.

63 Hopkins and Burton I985: I92.

64 Patroni: Supplementary Appendix I, nos I3, 20, 35, 36, 65, 68, 72; curatores: 72; both: 52.

65 Burton 1979 and Jacques I984.

66 Supplementary Appendix I, nos I 3 and 68 (son of a consul and father of a praefectus urbi).

67 See nn. 54-6 above.

68 Chastagnol I992: I72.
} 
of all clarissimi iumenes attested from the Antonine period until the accession of Diocletian confirms this interpretation. From all regions of the Roman Empire, thirty-six holders of this title are known. The number is interesting in itself. If every son, grandson and great-grandson of a senator had the right to call himself clarissimus iumenis, it would be difficult to explain why only so few holders of this title are attested. But it fits well with the hypothesis that this status designation normally denoted persons who exercised one of the administrative posts or military functions customarily exercised by elite males before they formally joined the Senate. A closer look at the identity of known clarissimi imuenes provides further corroboration. No fewer than fourteen of them are explicitly recorded as holders of one of the civilian or military offices reserved for laticlauii. ${ }^{69}$ Another ten exercised senatorial magistracies or priesthoods. ${ }^{70}$ For the remaining ten clarissimi iumenes, no offices are explicitly attested. ${ }^{7 \mathrm{I}}$ But at least four of them served (alongside their fathers) as patrons of their local communities. ${ }^{72}$ Another two were sons of equestrians; clearly, they had received the toga with the broad purple stripe because they planned to join the Senate. ${ }^{73}$ All of this supports Chastagnol's view that the term clarissimus iumenis denoted men in their high teens or early twenties in a preparatory stage for an officeholding career.

\section{Clarissimus Puer}

The status designation clarissimus puer is more interesting. Some holders of this title were infant children; the youngest attested clarissimus puer was six months old. ${ }^{74}$ Here at last, it might be thought, there is unambiguous proof that senatorial rank became hereditary in the early Empire - how else could it be explained that babies now held senatorial titles? But again, an in-depth examination of the evidence gives a more complex picture. Of fifty-six known clarissimi pueri, only twenty-eight ( 50 per cent) were descendants of a senator, ${ }^{75}$ fourteen ( 25 per cent) came from equestrian or municipal families, ${ }^{76}$ and the family origins of the remaining fourteen ( 25 per cent) clarissimi pueri cannot be identified. ${ }^{77}$ The fact that this title was only used so rarely, and often for boys who were not related to senators, makes it difficult to believe that it was understood as a hereditary status designation. More likely, it should be interpreted analogously to the status designation clarissimus iumenis. It seems that clarissimi pueri were boys below the age of maturity, who had the right (once they reached the requisite age) to obtain the latus clauus. If this is correct, the title implied an expectation that the person in question would run for senatorial magistracies. Conversely, clarissimi pueri who were unable or unwilling to embark on a political career would need to abandon their title. That this is precisely what happened is suggested by the fact that (as mentioned above) no non-officeholding clarissimi uiri are known.

\section{Clarissimae feminae and puellae}

The status designations for female relatives of senators emerge later than those for their male counterparts. The title clarissima femina appears for the first time in two texts

69 Supplementary Appendix 2, nos I, 2, 7, 8, 9, I4, I 5, I6, I9, 2 I, 22, 3 I, 35, 36.

70 Supplementary Appendix 2, nos 3, 4, 6, IO, I I, I7, I 8, 28, 29, 34 .

71 Supplementary Appendix 2, nos 5, I2, I3, 20, 23, 24, 25, 26, 27, 30, 32, 33.

72 Supplementary Appendix 2, nos I3, 20, 26, 30.

73 Supplementary Appendix 2, nos 25, 32 .

74 Supplementary Appendix 3, no. 24. Cf. also no. 45 (one year and some months old) and no. 35 (two years and nine months old).

75 Supplementary Appendix 3, nos 3, 4, 5, 6, I 2, I 4, I 5, I6, 20, 2 I, 22, 23, 24, 25, 27, 29, 30, 3 I, 32, 34, 39, 40, $4 \mathrm{I}, 42,45,53,54,56$.

76 Supplementary Appendix 3, nos I, 2, 8, 9, I3, I 8, I9, 26, 37, 44, 46, 49, 50, 52.

77 Supplementary Appendix 3, nos 7, IO, II, I7, 28, 33, 35, 36, 38, 43, 47, 48, 5I, 55 . 
produced in the reign of Antoninus Pius. However, the stonecutters employed two unique abbreviations for it: CL F and CLAR FEM. ${ }^{78}$ Only from the reigns of Marcus Aurelius and Commodus onwards is the status designation clarissima femina commonly used, and now uniformly abbreviated with the conventional CF. As Marie-Thérèse Raepsaet-Charlier observes, this suggests that it was only in this period that the title received some form of official sanction. ${ }^{79}$ Also around the same time, the Greek translation $\lambda \alpha \mu \pi \rho$ o $\alpha$ in is first attested. $^{80}$

In some ways, the adoption by the wives of senators of the new status designations was a surprising development. After all, the Senate defined itself as an officeholding elite, and in Rome, women (outside the field of religion) were normally excluded from exercising any form of public power. Moreover, in the early Empire, married women normally remained under the patria potestas of their fathers; they did not become part of the agnatic family of their husbands. The fact that the adoption of senatorial titles by women had nothing natural or inevitable about it is shown by the terminology employed by first-century and early second-century authors in talking about female relatives of senators. In this period, there was no word through which the status of the group of persons whom we call 'senatorial women' could be expressed; strikingly, collocations such as senatoria femina or senatoria puella are not attested in surviving texts. If they alluded to the rank of female relatives of senators, Latin authors employed circumlocutions such as mulier natalibus clara 'a woman of distinguished birth', splendida femina 'eminent woman' or inlustres feminae 'illustrious women'. ${ }^{8}$. The lack of language through which the rank of female relatives of senators could be designated suggests that the Romans had no clear conception that the wives of senators were a group which was different from, or superior to, other female members of the propertied elites of the Empire.

But once wives and daughters of senators began to employ clarissimate titulatures, their distribution follows similar rules than titles for men. The key passage is an excerpt from Ulpian's treatise De fideicommissis, included in the Digest:

Women who marry clarissimi are included in the expression clarissimae personae. The term does not encompass the daughters of senators, except if they marry uiri clarissimi. ${ }^{82}$

In Ulpian's view, daughters of senators were only allowed to call themselves clarissima femina if their husbands were senators too; if they married below their rank, they would lose their title. As Raepsaet-Charlier has shown, usage in surviving texts generally follows this principle. Most clarissimae feminae whose relatives can be identified were wives of senators. ${ }^{3}$ Conversely, daughters of senators who married below their rank were classified as equestrians. For example, during the Secular Games of 204, two daughters of senators who had married equestrians participated in the spectacles amongst the matronae equestres. ${ }^{84}$ There are exceptions. In several inscriptions, mostly put up on private estates of large landowners and dated to the reign of Commodus and to the second quarter of the third century, wives of senior equestrian officeholders bear

\footnotetext{
78 The first text is an unpublished inscription reported by Raepsaet-Charlier I987: I04 in which Aquilia Blaesilla is honoured for the construction of a building in Lepcis Magna, the second, CIL 6.I7543, a funerary inscription set up by some freedmen of Sallustia Frontina.

79 Raepsaet-Charlier I98I: I94-8.

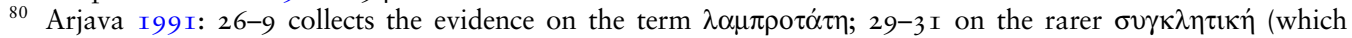
appears only in Asia Minor).

81 Plin., Ep. 8.1 8.8-ıо; Suet., Otho I; Tac., Ann. 3.49 with Chastagnol I992: I73.

82 Dig. I.9.8.

83 Raepsaet-Charlier I98I: 200-I 2.

84 Iulia Soemia $\left(P I R^{2}\right.$ I 704) and Aelia Gemellina $\left(P I R^{2}\right.$ A I058) in EAOR I 43 with Raepsaet-Charlier I983: I 8 5-8. See also Vedia Phaedrina $\left(P I R^{2}\right.$ V 327) and Claudia Crateia Veriana (Raepsaet-Charlier I987: no. 230) in IEph 980 with Raepsaet-Charlier I983: I89-9I.
} 
the title clarissima femina. ${ }^{85}$ Chastagnol explains this pattern by arguing that the rule reported by Ulpian had only been introduced by Caracalla and was later abolished; on his reading, both before and afterwards, daughters of senators who married equestrians continued to enjoy clarissimate status. ${ }^{86}$ By contrast, Raepsaet-Charlier suggests that clarissimae feminae with non-senatorial husbands received special dispensations from the emperor. ${ }^{87} \mathrm{~A}$ third possibility is that Ulpian's rule was not consistently enforced. This would explain why most inscriptions that attest clarissimae feminae without equestrian husbands come from private contexts.

In any case, even though female designations appear slightly later than their male counterparts, their distribution yet again highlights that clarissimate status was inextricably intertwined with officeholding. Like sons of senators who did not hold high office, so also daughters whose husbands did not engage in politics normally lost the title of their father.

\section{Summary}

The emergence of clarissimate titulatures was a significant development. The fact that there was now a set of titles which described not only senators themselves, but also their female relatives and underage males who had received the right to run for senatorial magistracies, marks a departure from previous practice. This change may be linked to other contemporaneous transformations in epigraphic protocol. As seen in the previous two sections, from the early second century C.E. onwards, commissioners of inscriptions and some elite authors began to experiment with new ways of describing the status of underage males who had received the right to run for high office, but who were not yet members of the Senate. ${ }^{88}$ Why did the line of demarcation between laticlauii and other members of local elites become an urgent issue from the Antonine period onwards? One explanation may be that the incorporation of growing numbers of provincial landowners into the Roman ruling class increased competition for the latus clauus. As laticlauii now frequently grew up in provincial cities and lived in the same milieu as other wealthy local landowners, it became more important to differentiate between persons who held office and fulfilled liturgies in their own municipalities and those who spent their political careers and invested their wealth in the imperial capital. If the new titles were responses to competitive tensions at the borderline between imperial and local elites, this would explain why this this new official terminology of status only began to be widely employed in the Antonine period and why the earliest texts containing clarissimate titulatures were commissioned not in Rome, but in the provinces or Italian cities. $^{89}$

But irrespective of how the rise of clarissimate titulatures is best explained, what matters for current purposes is that these new titles were not hereditary. All known clarissimi uiri

\footnotetext{
85 (I) CIL 6.I7543: a funerary inscription for a freedman family, set up on the Roman estate of Sallustia Frontina (PIR ${ }^{2}$ S IO4 and Raepsaet-Charlier I987: no. 664), elsewhere attested as wife of T. Flavius Athenagoras Agathos, procurator in the reign of Commodus; (2) CIL 5.7473: a dedication for Minerva set up in the late I 8 os by a slave on the Ligurian estate of Desticia Plotina, PIR 58 and Raepsaet-Charlier I987: no. 310, probably wife of P. Cominius Clemens, prefect of the fleet in Misenum; (3) CIL 7.I054=RIB I.I288= Dessau, ILS I425: a funerary inscription set up in High Rochester at an unknown date by Iulia Lucilla, $P I R^{2} \mathrm{I} 675$ and Raepsaet-Charlier I987: no. 437, for her husband, a praefectus cohortis; (4) Arminia Paullina (PIR ${ }^{2}$ A Io64), clarissima femina, is recorded in two fragmentary inscriptions published by Ballu 1907: 277 and found on her private estate in Timgad. She was the wife of equestrian C. Annius Flavianus and daughter of L. Aurelius Arminius Donatus, flamen perpetuus (from a first marriage). Her son Arminius Donatus is recorded as CP.

86 Chastagnol I979; I992: 173-99.

87 Raepsaet-Charlier I98I: 210-II; I983: I9I with n. 39.

88 See nn. 44-5I and 57 above.

89 See also nn. I27-9 below.
} 
are senators, and only persons who were preparing for a political career were described as clarissimi iuuenes or clarissimi pueri. Similarly, woman normally were only called clarissimae feminae or clarissimae puellae if their fathers or husbands served as officeholders. There is no evidence for the large number of non-officeholding persons of clarissimate status that would have existed if membership in the 'order' extended not only to officeholders themselves, but also to three generations of agnatic descendants. Like the legal, literary and epigraphic evidence, so also the distribution of clarissimate status designations does not fit the traditional view of senatorial heredity. The theory of a hereditary ordo senatorius, which encompassed three generations of agnatic descendants of senators, can thus safely be laid to rest. It is now time to explore the broader significance of this finding.

\section{PATRIA POTESTAS AND THE LEGAL CONSTITUTION OF THE SENATE}

From a certain perspective, it may seem surprising that the regulations reviewed in Section I of this paper had no more visible effects. After all, Mommsen was right that Augustus and his successors conferred special rights and duties on descendants of officeholders. On the face of it, it seems plausible to expect that these measures transformed the children, grandchildren and great-grandchildren of senators into a new legal class. But as the previous sections have shown, there are hardly any traces of this class in early imperial literature and epigraphy. It is not merely that the term ordo senatorius is never employed to describe relatives of senators. With the exception of Cassius Dio, Tacitus and some inscriptions that record the status of sons of officeholders who served as laticlauii and participated in various rituals in Rome, the new legal class supposedly created by Augustus' reforms does not appear in surviving texts at all. In particular, we hear nothing about the many politically inactive children, grandchildren and great-grandchildren of senators who lived in Italian or provincial cities and who now presumably were subject to a different set of laws than other local landowners. For example, the Album of Canusium, produced in 223 C.E., proudly lists the names of the senators and senior equestrian officeholders who served as patrons of this Apulian town. It also carefully catalogues all members of the local city council and praetextati (future city councillors, the municipal equivalent to laticlauii). But locally resident relatives of senators are not mentioned in the document. ${ }^{90}$ There is an apparent tension between the legal evidence, which suggests that the status of descendants of senators changed in the early Empire, and other sources, which are almost completely silent on the impact of the new laws.

One regulation poses the problem with particular urgency. It will be remembered that, according to the Pauli Sententiae, senators and three generations of their descendants were immune from fulfilling financial obligations in their hometowns. ${ }^{9 \mathrm{I}}$ On the face of it, it would seem that this rule removed thousands of wealthy landowners from the reach of city councils. But there is precious little evidence of the impact of this regulation. In early imperial legal literature, there is no other examination of the fiscal status of descendants of senators, despite the fact that three long chapters in the Codex Iustinianus, and an entire book of the Digest, discuss in detail the conditions under

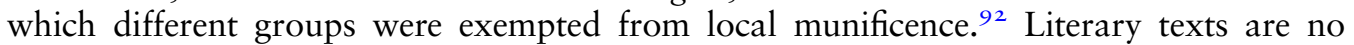
more forthcoming. For example, Pliny's native region of northern Italy was home to a

90 CIL 9.338 = Dessau, ILS 6I 2 I = ERCanosa I.35 (with useful commentary and prosopography).

91 Section I.5 above.

92 See esp. Dig. 50 and Cod. Iust. I0.32, I0.39 and I0.42. 
disproportionate number of senators. ${ }^{93}$ So was the province of Bithynia and Pontus which he governed towards the end of his life. ${ }^{94}$ But in none of his letters does Pliny touch on conflicts arising from attempts by municipalities to force descendants of senators to pay for local obligations. The same silence in epigraphy. Not a single inscription survives in which a senatorial relative advertised immunity from local liturgies, or that he or she had generously flouted such an immunity out of civic patriotism. All of this presents a riddle. As Fergus Millar noted long ago, the silence in legal, literary and epigraphic texts makes it hard to believe that children, grandchildren and great-grandchildren of senators were exempt from local financial obligations. ${ }^{95}$ But how then to make sense of the excerpt of the Pauli Sententiae, which unambiguously confirms this immunity?

In order to solve this puzzle, it is useful to look more closely at the ways in which the group of persons affected by Augustus' reforms is described in the texts discussed in section I above:
I.I (Lex Julia)
senators, children, grandchildren and great-grandchildren in the male line
I.2 (laticlauii)
'children of senators' (liberi senatorum)
I.3 (spectacles)

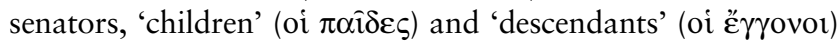
I.4 (Lex Claudia)
senators and their filii familias
I.5 (liturgies)
senators, children, grandchildren and great-grandchildren in the male line

Only the Lex Julia and the immunity from liturgies explicitly affected three generations of agnatic descendants (though Dio's vague statement that the exclusion from spectacles affected senators, their children and other हैy reform of the latus clauus was aimed at the 'children' of senators. Finally, the Lex Claudia targeted all persons who stood under their patria potestas. These differences are surprising. At first sight, it might seem as if each of those regulations affected a different group of relatives. But this conclusion would be premature. In order to understand the terminology employed in these texts, they need to be situated in the context of the Roman institution of patria potestas. ${ }^{96}$

As Yan Thomas has shown, until deep into the imperial period, Roman fathers normally exercised full property rights over the possessions of all their descendants in the male line. A pater familias could dispose of the belongings of these filii familias as he wished, even if they were adults, and even if they were senior officeholders of the Roman state. Emancipation was exceptionally rare; it normally happened only in cases where the pater familias remarried, and his first wife wished to prevent the children's share of her inheritance falling into his hands after her death. ${ }^{97}$ If the legal structure of the Roman family is correctly understood, it becomes clear that all the regulations quoted above specifically targeted the persons who stood under the patria potestas of senators. This is most obvious in the case of the Lex Claudia. Livy explicitly writes that this law applied to 'senators and whoever had a senator as father'. ${ }^{98}$ The same is also true for the reform of the latus clauus. Suetonius calls the group of persons who had the right to receive the toga with the broad purple stripe liberi senatorum. ${ }^{99}$ This expression is

\footnotetext{
93 Alföldy I982 and I984.

94 Halfmann I982: 637-9.

95 Millar I983: 87-9I, esp. 88-9.

96 Kaser I975: 34I-52 surveys the functioning patria potestas in the High Empire. Saller I994: I02-32 looks at the social and demographic pressures which mitigated the uitae necisque potestas of a pater familias in practice. Arjava 1998 traces the survival of patria potestas into Late Antiquity.

97 Thomas I982 explores the effects on senior officeholders of the Roman state of the subjection to the patriarchal authority of their fathers.

98 See n. 28 above.

99 See n. I7 above.
} 
usually translated as 'children of senators'. But as Ulpian points out, the term has a broader meaning:

By the term liberi senatorum we mean not merely the sons of a senator, but all whom he is claimed to have begotten, or his children are claimed to have begotten, irrespective of whether they are the natural or adopted children of the senators from whom they are claimed to be born. But if somebody is born from a daughter of a senator, we need to look at the status of the father. ${ }^{\text {I00 }}$

Liberi senatorum were not merely the 'children' of a senator, but all agnatic descendants who normally stood under his patria potestas. The same is true for the Lex Julia and the immunity from liturgies. When a Roman law affected the children, grandchildren and great-grandchildren of a person, it was another way of saying that it affected all his potential filii familias: a great-grandson was the most distant possible descendant who could theoretically fall under his patria potestas. ${ }^{\text {IOI }}$ Significantly, jurists call the group of persons affected by the marriage legislation liberi senatorum. ${ }^{\text {IO2 }}$ As with the other regulations, so also the Lex Julia and the immunity from liturgies only affected those relatives of a senators who fell under his patria potestas during his lifetime. ${ }^{\mathrm{IO}} 3$

If Augustus' laws specifically targeted the filii familias of senators, this solves the problem posed by the excerpt of the Sententiae Pauli. The immunity from liturgies only extended to those descendants of senators who stood under their patria potestas. As long as a senator was alive, assets controlled by all his descendants in the male line normally were his legal property. By forcing one of these filii familias to pay for public services, a municipality would have been able to extract wealth from a senator against his will. It is not surprising that in the view of the author of the Pauli Sententiae, this was illegal. But after a senator's death this immunity ceased to be valid. This explains why there is no other evidence for conflicts around the fiscal status of descendants of senators. Unless they embarked on an officeholding career in Rome, they would again be liable for liturgies in their hometowns.

If this interpretation is correct, this also explains why we hear so little about the group of persons affected by Augustus' reforms in early imperial texts. The new regulations affected far fewer people than is usually thought. Richard Saller's demographic simulations give a rough idea of who normally fell under the patria potestas of a Roman head of household. According to his 'senatorial' lifetable, only one-quarter of Roman elite males (27 per cent) had a paternal grandfather at birth; at age twenty-five, this ratio drops to one in a hundred (I per cent). Significantly too, by this time, only around two-fifths of males (39 per cent) still had a father. ${ }^{\text {IO4 }}$ These figures suggest that Augustus' regulations normally affected the children of senators, not their grandchildren or great-grandchildren. Moreover, most of the persons affected by the legislation were still underage. Interestingly, the distribution of clarissimate status designation is in line with Saller's estimates. Of the forty-six clarissimi iumenes and clarissimi pueri who have known senatorial ancestors,

\footnotetext{
100 Dig. I.9.I0.

101 For the general principle, see Dig. 50.I6.220.pr. For applications of it in practice, see, for example, Cod. Iust. 4.28.6.I; 9.4I.II; Dig. I.6.4; I.6.5; I.7.2.pr; I.7.28; 28.2.25.I; 28.2.29; 37.8.I and 38.I6.I.7.

102 See Celsus in Dig. 23.2.23, 'Lege Papia cauetur omnibus ingenuis praeter senatores eorumque liberos libertinam uxorem habere licere' ('The Lex Papia stipulates that all freeborn persons except senators and their children are allowed to have a freedwoman as wife'), and Ulpian cited in n. Io० above.

103 As usual in Roman law, this included unborn children in their mothers' wombs, but not persons born more ten months after a senator's death or loss of rank: see Thomas 2007 on the general principle and Dig. I.9.7.I on its application to descendants of senators. The status of emancipated children of senators was controversial. In the view of Paul in Dig. I.9.6.pr., they were not affected by the legislation. By contrast, Ulpian in Dig. I.9.7.I.pr. argues they should be treated 'as if' they were the filii familias of senators.

104 Saller I994: 52 .
} 
forty-three (93 per cent) were sons, three $(7$ per cent) grandsons and nobody the great-grandson of a senator. ${ }^{\text {IO5 }}$

In sum, the Roman institution of patria potestas clarifies the purpose of Augustus' reforms. The new regulations did not create a hereditary aristocracy, which extended multiple generations after a senator's death, but merely conferred some new rights and duties on those persons who stood under his patriarchal authority during his lifetime. This explains why we only hear about them in the context of imperial rituals conducted in Rome, or when they exercised one of the administrative or military positions reserved for laticlauii. In practice, most of these liberi senatorum were children or young adults who lived in the same household as their parents.

\section{AMBITION AND WITHDRAWAL}

If it is recognised that Augustus' regulations specifically targeted the filii familias of senators, it then becomes clear that they had much earlier precedents. The original version of the Lex Claudia was passed in 2 I 8 B.C.E. ${ }^{\text {I06 }}$ Similarly, when in the late second century B.C.E. the lex repetundarum created a new court that allowed provincials to bring suits against Roman magistrates, its jurisdiction extended not only to senators, but also to all persons 'whose father was a senator'. ${ }^{\text {I07 }}$ The municipal law of Urso (modern Osuna near Seville) from 44 B.C.E. included a provision that 'senators of the Roman people' and 'sons of senators of the Roman people' had the right to sit on designated seats in spectacles. ${ }^{\text {IO8 }}$ At the same time, it is true that emperors intervened more aggressively into the lives of the filii familias of officeholders than republican lawmakers. Not only had descendants of senators never been subjected to so many new regulations in such a short time; Augustus' reforms were also more ambitious in scope than earlier republican laws. This raises a new question. What motivated this increased interest of the imperial government in the descendants of senators?

On the one hand, the new regulations pursued ideological objectives. By allowing young elite males to wear the latus clauus and by prohibiting them from performing in spectacles or marrying into servile families, Augustus advertised that he was committed to protecting their freedom and moral integrity. Future officeholders would be recruited from the same social class as in the Republic and their honour unsullied through contact with servile populations or occupations. These measures formed part of a broader effort by the Augustan regime to involve the children of officeholders in public life. It has already been observed that laticlauii had a prominent role in imperial funerals. ${ }^{\text {IO9 }}$ Sons of senators also appear several dozen times in the records of the elite priesthood of the fratres aruales: 'freeborn boys, sons of senators whose fathers and mothers are still alive, taking the offering to the altar in libation dishes'. ${ }^{\text {Iо }}$ Even more important was their participation in the transuectio equitum, the annual parade of the equestrian order on the Ides of July. ${ }^{\text {II }}$ Each year, six laticlauii were handpicked to serve as seuiri equitum

\footnotetext{
105 Supplementary Appendix 2, nos I 2 and 20 and Supplementary Appendix 3, no. 34.

106 Section I.4 above.

107 CIL I.583, 1. 2, 'quoius pater senator siet'. On the Lex Repetundarum, see further Lintott I992; Crawford I996: I.39-II2 (no. I); Williamson 2005: 30I-6.

${ }_{108}$ HEp Online 3263 , ch. I 27.3, 'si quis senator $\mathrm{p}$ (opuli) R(omani) est erit fuerit et si quis senatoris $\mathrm{f}$ (ilius) $\mathrm{p}$ (opuli) R(omani) est erit fuit'. For text, translation and commentary, see, most conveniently, Crawford I996: I.393-454 (no. 25). See further D’Ors I953: I67-280; Rüpke 2006.

109 See nn. 20-3 above.

110 Commentarii fratrum Arualium 48.9-10, 'pueris ingenuis patrimis et matrimis senatorum filis referentibus ad aram in pateris' and passim with the commentary by Scheid I990: 539-4I.

111 This ritual is excellently discussed by Weinstock I937; Demougin I988: I35-88; Davenport 2019: 380-95.
} 
Romanorum, leaders of the faux military units (turmae) into which the ordo equester was divided. ${ }^{\text {II } 2}$ Some funerary reliefs represent this ritual, showing the deceased participating in the procession on horseback, symbol of his equestrian rank, but wearing the shoes (calcei) of senators, representing the promise of a future promotion into the Senate. ${ }^{\text {II }^{3}}$ In sum, by regulating the lives of future members of the imperial elite, and by involving them prominently in state ceremonial, Augustus staked out a claim that he wished to foster traditional forms of virtue and political commitment amongst them.

On the other hand, the new regulations had material effects. They contributed to keeping the wealth of senators within their families. The immunity from local liturgies prevented the alienation of assets from which officeholders would finance their political careers. Similarly, as Andrew Wallace-Hadrill pointed out, by preventing descendants of slaves from becoming the heirs of senators, the Lex Julia encouraged the intergenerational transmission of wealth within elite families: 'Augustus aimed to stabilise the family in order to stabilise the transmission of property, and consequently of status, from generation to generation.' ${ }^{\text {II } 4}$ It is also interesting that Hadrian expanded the scope of the Lex Claudia to include the capital intensive business of tax-farming. II 5 By outlawing this form of investment, he reduced the risk that a sudden default of provincial debtors would prevent Roman magistrates from fulfilling their financial obligations. Taken together, the diverse set of regulations introduced by Augustus and his successors may thus be said to have pursued a unified purpose. By safeguarding the honour and wealth of filii familias of senators, the imperial government made it easier for them to follow their fathers' careers.

Such efforts to motivate descendants of officeholders to participate in politics were particularly urgent in the 20 s and early IOs B.C.E. when most of these measures were passed. In the civil wars, many senators been killed and hundreds of 'new men' had been admitted to the imperial elite. ${ }^{\text {I } 6}$ But even after the return to peace, officeholding families remained reluctant to join the Senate. Cassius Dio notes that several times in these years Augustus faced a shortage of qualified candidates for magistracies; as Amy Russell points out, the concentration of power at the imperial court and the decline in the power of officeholders led to 'a crisis of senatorial recruitment'. ${ }^{\mathrm{I} 7}$ The policies pursued by Augustus and his advisers in this period were designed to reverse these trends. In 29, I 8 and I3 B.C.E., three reviews of the Senate were carried out, during which 'unworthy' members were expelled and the overall size of the assembly reduced from more than I, 000 to around 600. ${ }^{\text {II } 8}$ Also in I 8 B.C.E. or soon afterwards, Augustus increased the minimum census for senators from 400,000 to I,000,000 HS. As Claude Nicolet and Andrew Pettinger note, these reforms were not intended to weaken ancient officeholding families; notably, for those who could not fulfil the new wealth requirement, the emperor made up the difference from his own private fortune. On the contrary, by reducing the number of senators and raising the census, Augustus emphasised the greater dignity (dignitas) which elevated the ruling elite of the Empire

\footnotetext{
112 Demougin I988: 225-43 carefully examines the prosopography and function of seuiri. On the place of this honour in the senatorial cursus, see further Eck 1974: I6I-3; Demougin 1982: 89-90; Duncan-Jones 20I6: 24-5.

113 Spalthoff 2010: 49-53 and tables 40-3.

114 Wallace-Hadrill I98I, quoting 253.

115 See n. 29 above.

116 Syme I939: 78-96 and 349-68; Wiseman I97I: 9-IO and I83; Osgood 2006: 25 I-97 elegantly evoke the ways in which the civil wars reshaped the social composition of the Roman élite.

117 Cass. Dio 54.26; 54.30.2; 5 5.I 3.6 with Chastagnol I980; I992: 49-56; Rich I990: 204, 209 and 2I 5 ; Russell 20I9: 336-40, quoting 336 .

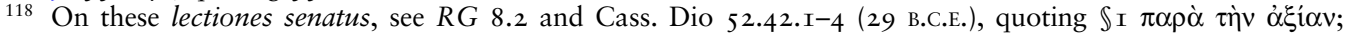
54.I3-I4 (I 8 B.C.E.); 54.26.3-5 (I3 B.C.E.) with Talbert I984: IO-I2; Chastagnol I992: 23-30; Eck I998: 65-7.
} 
over other citizens. ${ }^{\mathrm{I} 9}$ The regulations on filii familias of senators need to be situated in the same context. By incentivising them to participate in politics and exhibiting them to the public in state rituals, Augustus advertised his determination to restore social distinctions of an imagined past and to moderate social mobility; as John Richardson puts it, 'the intention was clearly that membership in the senate would pass down the generations of a senatorial family'. ${ }^{\mathrm{I} 20}$

This goal did not lose urgency under Augustus' successors. As Hopkins and Burton have shown, social mobility in the early imperial Senate was higher than it had been in the late Republic. ${ }^{\text {II }}$ Powerful structural forces worked against any attempts by Augustus and his successors to slow down the rate of renewal within the imperial elite. First, while the fiction that the emperor was the first magistrate of a restored Republic brought many symbolic and material benefits to senators, it also exposed them to great risks. The persecutions and conspiracies which marked the history of early imperial Rome are indicative of the violence generated by a political system in which any successful senator was a potential emperor. The high incidence of violent death amongst early imperial senators disrupted continuity within the Senate. ${ }^{\text {I22 }}$ Second, Roman political culture had always associated monarchy with slavery. It is true that early imperial officeholders went out of their way to challenge this preconception. Shadi Bartsch and Matthew Roller have exposed the rhetorical techniques and ideologies developed by first- and early second-century authors to reconcile service to the emperor with the preservation of their inner freedom. ${ }^{\text {I23 }}$ Rose MacLean has observed that senators now also discovered the old servile quality of obedience as a positive virtue. ${ }^{\text {I } 24}$ But not all were convinced that the tensions between liberty and monarchy could be quite so easily resolved. Behind reassertions of the value of state service as the only appropriate arena in which elite males could prove their worth lurked widespread anxieties that the experience of civil war and autocracy had fatally undermined the freedom and moral integrity of the Senate. ${ }^{\text {I25 }}$ In the view of many Roman men, a retreat from politics (otium) was preferable over membership in a slavish and morally corrupted ruling class. ${ }^{\text {I26 }}$

Third, in the first two centuries C.E., ever larger numbers of provincial property-owners obtained Roman citizenship and became eligible to join the Senate. ${ }^{\text {I27 }}$ Already in the reign of Antoninus Pius, most consuls (the best attested group of senators) came from outside Italy. ${ }^{\text {I28 }}$ The gradual incorporation of provincials into the imperial elite intensified competition. While the number of candidates eligible for membership multiplied, the overall size of the Senate remained steady. I have suggested above that the intensification of rivalry explains the quick spread of clarissimate titulatures; the new terminology provided a language to describe the boundary between those members of local elites who had received the right to run for senatorial magistracies and those who spent their

119 Nicolet I984b: 90-6 (census) and Pettinger 2019, especially 60-2 (reduction in numbers).

120 Richardson 20I2: I 18.

121 Hopkins and Burton I985.

122 Winterling I999 and 20I I are the most sophisticated recent explorations of the paradoxical political system introduced by Augustus. Suggestive of the scale of violence in some periods is the remark in Suet., Claud. 29.2 that in Claudius' reign alone thirty-five senators were killed. As Hahn and Leunissen I990: 60-I note, this is equivalent to more than one-tenth of the senators appointed during this period.

123 Bartsch I994; I997; Roller 200I.

124 MacLean 201 8: 82-I03.

125 Wallace-Hadrill I982 and Lavan 20I I trace the anxieties around moral decline amongst the early imperial elite.

126 Leppin I992; Dewar 20I3; Osgood 20I4 examine alternative visions of the good life.

127 Sherwin-White I973: 220-90 and Lavan 2016 map the progress of enfranchisement until the Constitutio Antoniniana. Hammond I957 and Duncan-Jones 20I6: 6I-72 explore the changing geographical make-up of the early imperial Senate.

128 Alföldy 1977: 64, updated by Eck 2013, shows that already in the Antonine period most consuls came from provincial families. 
political careers in their municipalities. ${ }^{\mathrm{I} 29}$ In any case, like the high incidence of violence and political withdrawal, so also the accelerated integration of provincial landowners into the imperial elite ensured that the Senate renewed itself more quickly in the early Empire than it had in the late Republic.

This increased turnover provides a context for the new interest shown by Augustus and his successors in the lives of the descendants of senators. In the face of widespread anxiety that the introduction of monarchy would lead many of the men who were best qualified for leadership positions in the Roman state to withdraw from politics, and enable unworthy candidates to reach high office, emperors sought to incentivise as many sons of senators as possible to follow their fathers' careers. In this sense, Mommsen and other modern scholars were entirely correct if they discerned in early imperial legislation a concern to facilitate the intergenerational transmission of status. The regulations were designed to compel sons of senators to embark on an office holding career; as Nicolet puts it, 'becoming a senator would in principle become an obligation for them.' ${ }^{30}$ Where scholars such as Mommsen and Nicolet went wrong was in thinking that the legislation simply enshrined into law an underlying reality in which sons of senators almost always followed the careers of their fathers. The opposite was the case. Precisely because the Senate had become more unstable as a social group, emperors sought to slow down the pace of turnover within it.

VII IMPERIAL STATE AND SENATORIAL WEALTH

One final question remains. Why were Augustus and his successors so keen to encourage heirs of leading families to participate in politics? After all, from a certain perspective, it was in the interest of monarchs to reduce the power of their highest-born subjects. In the view of Hopkins and Burton, Augustus and his successors deliberately sought to weaken the power of old senatorial families in order to shore up their own authority: 'aristocrats were those whose social power most threatened the emperors' supremacy and survival'. ${ }^{\text {I I }}$ Why did emperors nevertheless seek to convince the sons of officeholders to follow their fathers' careers? Ideological reasons certainly played a role. In the view of Roman authors, the children of senatorial officeholders, prominent equestrians and other wealthy citizens were more likely to exhibit the exceptional forms of commitment to the Roman state expected from holders of senior magistrates than men of low birth or servile descent. Cassius Dio expressed these preconceptions in his speech for Maecenas: 'for it is not possible either for a man of any real worth to be naturally lacking in political dedication $\left(\varphi \rho \operatorname{vov}_{\mu \alpha \alpha}\right)$, or on the other hand for a man sprung from a servile sphere of life to acquire such dedication'. ${ }^{132}$

But ideology was not the only reason why Augustus and his successors strove to stabilise the rate of turnover within the elite. There were also good economic motives to encourage the descendants of senators and other large landowners of free birth to participate in politics. In comparison to other ancient states, Rome had an extremely wealthy elite, ${ }^{\text {I3 } 3}$

\footnotetext{
129 See Section IV.5 above.

130 Nicolet I976: 35, 'devenir sénateur serait une obligation de principe pour eux'. See also 38, 'l'obligation, au moins morale, faite aux fils et descendants de sénateurs de briguer à leur tour les honneurs' ('the obligation, at least a moral one, imposed upon sons and descendants of senators to compete for offices'). Also Mommsen I 887: 469 assumes that they 'normally' ('regelmässig') followed their fathers' careers.

131 Hopkins and Burton I985: I2I.

132 Cass. Dio 52.8.5.

133 Scheidel 20I 7: 62-85 notes that levels of wealth accumulation in Rome and China exceeded those of previous states and would not be reached again until the nineteenth century. Lewis 2007: I I 5 observes that even the estates of the great landowners of Han China were much smaller than those of their Roman counterparts.
} 
but a very weak state infrastructure. ${ }^{\mathrm{I} 34}$ As a result, many key public functions were financed from the private fortunes of leading citizens. In particular, ambitious politicians invested vast sums in providing spectacles and other forms of largesse for the Roman people. ${ }^{\mathrm{I}}{ }^{5}$ This reliance on private munificence posed two problems for emperors. On the one hand, it was not in their interest that officeholders would provide outsize investments in popular entertainments. If another senator showed too much generosity towards the populace, this might have been taken as a threat to the emperor's role as supreme patron of the populus Romanus. In order to reduce this risk, Augustus and his successors asserted a monopoly on the most impressive forms of public self-display, such as triumphs and public building, and introduced expenditure limits on large-scale spectacles. ${ }^{\text {I36 }}$

On the other hand, if they wished to maintain the level of provision to which the Roman people had become accustomed in the Republic, monarchs could not completely forgo the wealth of the imperial elite. Yet, since the most spectacular prizes for political achievement were now reserved for the emperor and his relatives, senators no longer had the same incentives to invest their money in public functions as they had in the Republic. Augustus and his successors solved this problem by making it obligatory for officeholders to invest some of their private money into select public functions. For example, quaestors had to make large cash payments into a fund for the construction of roads, praetors were asked to organise a series of expensive spectacles for the Roman populace and the curator aquarum was expected to invest some of his own money into the improvement of the water supply. ${ }^{\mathrm{I}} 37$ This system allowed emperors to harness the wealth of senators without risking serious challenges to their own position. But the vital role played by senators in the maintenance of civic infrastructure had an important corollary. It provided a powerful incentive for emperors to ensure that as many descendants of senators as possible would participate in politics. For if heirs of officeholders withdrew from political life, the imperial state would no longer be able to draw on their wealth to finance munificence in Rome. There was thus not only a powerful ideological reason, but also a strong economic motive, for emperors to encourage sons of senators to participate in politics.

In sum, by making it easier for the filii familias of officeholders to attain the same status as their ancestors, Augustus and his successors not only sought to fulfil the ideological expectation that a good ruler would share his power with the descendants of the most respectable families in the Empire, but also advanced their own material interests. They ensured that there would always be a sufficient number of wealthy landowners who were able and willing to serve as magistrates, and invest their private fortunes in munificence in Rome.

\section{St John's College, Cambridge \\ jw439@cam.ac.uk}

\footnotetext{
134 Scheidel 2015: 165-74 brings out the weakness of Roman infrastructure in comparison with China.

135 Veyne I976: 375-537 remains the classic analysis of Roman euergetism. Lewis 2009: I34 highlights the difference with China, in which many of the functions carried out in the Roman Empire by senators and local notables were fulfilled by a state bureaucracy.

136 Veyne I976: 685-9 and Eck I984 trace the impact of monarchy on senatorial self-display in Rome.

137 On the euergetic obligations of quaestors, praetors and curatores aquarum, see Veyne 1976: 688-9 and Talbert I984: 58-66. Peachin 2004 analyses the role played by the curator aquarum in the distribution of water rights.
} 
SUPPLEMENTARY MATERIAL

For Supplementary Material for this article, please visit https:/doi.org/IO.IOI7/ Soo 7543582000 I 2 I 5

\section{BIBLIOGRAPHY}

Abbreviations for epigraphical publications follow Année épigraphique.

$P_{I R^{2}}=$ Prosopographia Imperii Romani, 2nd edn, 8 vols, Berlin I933-20I 5, with index and addenda at http://pir.bbaw.de

Alföldy, G. I977: Konsulat und Senatorenstand unter den Antoninen. Prosopographische Untersuchungen zur senatorischen Führungsschicht, Bonn.

Alföldy, G. I982: 'Senatoren aus Norditalien. Regiones IX, X und XI', in Panciera I982, 2.603-50. Alföldy, G. I984: Römische Statuen in Venetia et Histria. Epigraphische Quellen, Heidelberg.

Alföldy, G. I986: 'Die Laufbahn der Konsuln und die Erblichkeit des Konsulats unter den Antoninen. Ein Diskussionsbeitrag', in G. Alföldy, Die römische Gesellschaft. Ausgewählte Beiträge, Stuttgart, I39-6I.

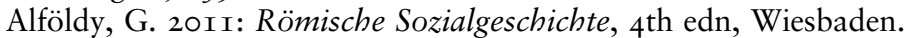

Archi, G. G., David, M., Levy, E., Marichal, R. and Nelson, H. L. W. (eds) I956: Pauli sententiarum fragmentum Leidense (Cod. Leid. B.P.L. 2589), Leiden.

Arjava, A. I99I: 'Zum Gebrauch der griechischen Rangprädikate des Senatorenstands in den Papyri und Inschriften', Tyche 6, I7-35.

Arjava, A. I998: 'Paternal power in late Antiquity', Journal of Roman Studies 88, I47-65.

Ash, R. 20I8: Tacitus: Annals Book XV, Cambridge.

Ballu, A. 1907: 'Rapport sur les fouilles archéologiques exécutées en I906 par le Service des monuments historiques de l'Algérie', Bulletin archéologique du Comité des travaux historiques et scientifiques 26, 23I-30I.

Baltrusch, E. I989: Regimen morum. Die Reglementierung des Privatlebens der Senatoren und Ritter in der römischen Republik und frühen Kaiserzeit, Munich.

Bartsch, S. I994: Actors in the Audience: Theatricality and Doublespeak from Nero to Hadrian, Cambridge, MA.

Bartsch, S. I997: Ideology in Cold Blood: A Reading of Lucan's Civil War, Cambridge, MA.

Burton, G. I979: 'Curator rei publicae, towards a reappraisal', Chiron 9, 465-88.

Burton, G. I995: 'The inheritance of the consulate in the Antonine period: a problem revisited', Phoenix 49, 2I8-31.

Burton, G. 20I2: 'Senate: imperial age', in S. Hornblower and A. J. Spawforth (eds), Oxford Classical Dictionary, $4^{\text {th }}$ edn, Oxford, I346-7.

Caldelli, M. L. and Gregori, G. L. (eds) 20I4: Epigrafia e ordine senatorio, 30 anni dopo, 2 vols, Rome.

Campbell, B. I975: 'Who were the "Viri Militares"?', Journal of Roman Studies 65, I I-3 I.

Chastagnol, A. I973: 'La naissance de l'ordo senatorius', Mélanges de l'École française de Rome Antiquité 85, 583-607 (= C. Nicolet (ed.), Des ordres à Rome, Paris, I984, I75-98).

Chastagnol, A. I979: 'Les femmes dans l'ordre sénatorial. Titulature et rang social à Rome', Revue historique 262, 3-28.

Chastagnol, A. I980: 'La crise de recrutement senatorial des années i6-II av. J.-C.', in M.

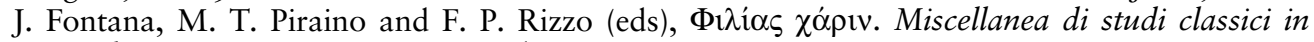
onore di Eugenio Manni, Rome, 6 vols, 2.463-76.

Chastagnol, A. I992: Le Sénat romain à l'époque impériale. Recherches sur la composition de l'Assemblée et le statut de ses membres, Paris.

Christol, M. 200I: 'Laticlavius', Zeitschrift für Papyrologie und Epigraphik I35, 225-32.

Cohen, B. I975: 'La notion d' “ordo” dans la Rome antique', Bulletin Association Guillaume Budé $34,259-82$.

Corbier, M. 2006: 'Titres et rangs', in S. Demougin, X. Loriot, P. Cosme and S. Lefebvre (eds), H.-G. Pflaum. Un historien du XX $X^{\mathrm{e}}$ siècle. Actes du colloque international, Paris les 21, 22, et 23 octobre 2004, Geneva, 503-13. 
Crawford, M. H. I996: Roman Statutes, 2 vols, London.

Crook, J. A. 1967: Law and Life of Rome, 90 B.C.-A.D. 212 , London.

Davenport, C. 2019: A History of the Roman Equestrian Order, Cambridge.

Demougin, S. I982: 'Uterque ordo. Les rapports entre l'ordre sénatorial et l'ordre équestre sous les Julio-Claudiens', in Panciera I982, I.73-104.

Demougin, S. 1988: L'ordre équestre sous les Julio-Claudiens, Collection de l'École française de Rome ro8, Rome.

Dewar, M. J. 20I3: Leisured Resistance: Villas, Literature and Politics in the Roman World, London.

D'Ors, A. I953: Epigrafía jurídica de la España romana, Madrid.

Duncan-Jones, R. P. 20I6: Power and Privilege in Roman Society, Cambridge.

Eck, W. I974: 'Beförderungskriterien der senatorischen Laufbahn dargestellt an der Zeit von 69 bis I 38 n.Chr.', Aufstieg und Niedergang der römischen Welt 2.I, I 5 8-228.

Eck, W. I984: 'Senatorial self-representation: developments in the Augustan period', in F. Millar and E. Segal (eds), Caesar Augustus: Seven Aspects, Oxford, I29-68.

Eck, W. I998: Augustus und seine Zeit, Munich.

Eck, W. I999: 'Arrecinus 2', Der Neue Pauly 2.26.

Eck, W. 2007: 'Befund und Realität. Zur Repräsentativität unserer epigraphischen Quellen in der römischen Kaiserzeit', Chiron 37, 49-64.

Eck, W. 20I3: 'Die Fasti Consulares der Regierungszeit des Antoninus Pius', in W. Eck, B. Fehér and P. Kovács (eds), Studia epigraphica in memoriam Géza Alföldy, Bonn, 69-90.

Eck, W., Caballos, A. and Fernández, F. I996: Das Senatus consultum de Cn. Pisone patre, Munich.

Galinsky, K. I98 I: 'Augustus' legislation on morals and marriage', Philologus I25, I26-44.

Galsterer, H. 2000: 'Ordo II. Staatsrecht', Der Neue Pauly 9.I3-I4.

Green, E. C., Lewis, A. D. E. and Crawford, M. H. I996: 'Lex Iulia de maritandis ordinibus, lex Papia Poppaea', in Crawford I996, 2.80I-Io.

Groag, E. I907: 'Notizen zur Geschichte kleinasiatischer Familien', Jahreshefte des Österreichischen Archäologischen Instituts 10, 282-99.

Hahn, J. and Leunissen, P. M. M. I990: 'Statistical method and inheritance of the consulate under the early Roman Empire', Phoenix 44, 60-8I.

Halfmann, H. I982: 'Die Senatoren aus den kleinasiatischen Provinzen vom I. bis zum 3. Jahrhundert (Asia, Pontus-Bithynia, Lycia-Pamphylia, Galatia, Cappadocia, Cilicia)', in Panciera 1982, 2.603-50.

Hammond, M. I957: 'Composition of the Senate, A.D. 68-235', Journal of Roman Studies 47, 74-8 I.

Heil, M. 20I 5: 'Die Genese der Rangtitel in den ersten drei Jahrhunderten', in A. B. Kuhn (ed.), Social Status and Prestige in the Graeco-Roman World, Stuttgart, 45-62.

Hillebrand, S. 2007: 'Der Vigintivirat. Prosopographische Untersuchungen für die Zeit von Augustus bis Domitian', unpublished Ph.D. thesis, Ruprecht-Karls-Universität, Heidelberg.

Hirschfeld, O. I90I: 'Die Rangtitel der römischen Kaiserzeit', Sitzungsberichte der Königlich Preussischen Akademie der Wissenschaften, 579-610 (= O. Hirschfeld, Kleine Schriften, Berlin, I9I3, 646-8I).

Hopkins, K. and G. Burton I985: 'Ambition and withdrawal: the senatorial aristocracy under the emperors', in K. Hopkins, Death and Renewal, Cambridge, I 20-200.

Jacques, F. I984: Le privilège de liberté. Politique impériale et autonomie municipale dans les cités de l'Occident romain (I6I-244), Collection de l'École française de Rome 76, Rome.

Jacques, F. I987: 'L'éthique et la statistique. À propos du renouvellement du Sénat romain $\left(\mathrm{I}^{\mathrm{er}}-\mathrm{III}^{\mathrm{e}}\right.$ siècles de l'Empire)', Annales: Economies, Sociétés, Civilisations 42, I287-303.

Kaser, M. I975: Das römische Privatrecht, Vol. 2. Die nachklassischen Entwicklungen, Handbuch der Altertumswissenschaft I0.3.3.2, 2nd edn, Munich.

Lavan, M. 20I I: 'Slavishness in Britain and Rome in Tacitus' Agricola', Classical Quarterly 6I, 294-305.

Lavan, M. 2016: 'The spread of Roman citizenship, I4-2 I 2 C.E.: quantification in the face of high uncertainty', Past \& Present 320, 3-46.

Leppin, H. I992: 'Die Laus Pisonis als Zeugnis senatorischer Mentalität', Klio 74, 22 I-36.

Levick, B. I982: 'A note on the Latus Clavus', Athenaeum 79, 239-44.

Levick, B. I983: 'The senatus consultum from Larinum', Journal of Roman Studies 73, 97-I I 5.

Levy, E. I930: 'Paulus und der Sentenzenverfasser', Zeitschrift der Savigny-Stiftung für Rechtsgeschichte 50, 272-94 (= E. Levy, Gesammelte Schriften zu seinem achtzigsten Geburtstag, ed. W. Kunkel and M. Kaser, 2 vols, Cologne, I963, I.99-II4).

Lewis, M. E. 2007: The Early Chinese Empires: Qin and Han, Cambridge, MA. 
Lewis, M. E. 2009: 'Gift circulation and charity in the Han and Roman Empires', in W. Scheidel (ed.), Rome and China: Comparative Perspectives on Ancient World Empires, New York, I2 I-36.

Liebs, D. 1989: 'Der Sentenzenverfasser (Pseudo-Paulus I)', in R. Herzog (ed.), Handbuch der lateinischen Literatur der Antike, Vol. 5. Restauration und Erneuerung 284-374 n.Chr., Munich, 65-7.

Lintott, A. W. I992: Judicial Reform and Land Reform in the Roman Republic: A New Edition, with Translation and Commentary, of the Laws from Urbino, Cambridge.

MacLean, R. 2018: Freed Slaves and Roman Imperial Culture: Social Integration and the Transformation of Values, Cambridge.

McGinn, T. A. J. I99I: 'The Augustan marriage legislation and social practice: elite endogamy versus male "marrying down", in J. J. Aubert and B. Sirks (eds), Speculum Iuris: Roman Law as a Reflection of Social and Economic Life in Antiquity, Ann Arbor, MI, 46-93.

Mette-Dittmann, A. I991: Die Ehegesetze des Augustus. Eine Untersuchung im Rahmen der Gesellschaftspolitik des Princeps, Stuttgart.

Millar, F. I983: 'Empire and city, Augustus to Julian: obligations, excuses and status', Journal of Roman Studies 73, 76-96 (= F. Millar, Rome, the Greek World, and the East, Vol. 2: Government, Society and Culture in the Roman Empire, ed. H. M. Cotton and G. M. Rogers, Chapel Hill, NC, 2002, 336-7I).

Millar, F. I992: The Emperor in the Roman World (3 I BC-AD 337), 2nd edn, London.

Mommsen, T. I887: Römisches Staatsrecht, Vol. 3. Bürgerschaft und Senat, 3 rd edn, Leipzig.

Nicolet, C. I976: 'Le cens senatorial sous la republique et sous Auguste', Journal of Roman Studies $66,20-38$.

Nicolet, C. I984a: 'Les ordres romains: définition, recrutement et fonctionnement', in C. Nicolet (ed.), Les ordres à Rome, Paris, 7-2I.

Nicolet, C. I984b: 'Augustus, government and the propertied classes', in F. Millar and E. Segal (eds), Caesar Augustus: Seven Aspects, Oxford, 89-I 28.

Osgood, J. 2006: Caesar's Legacy: Civil War and the Emergence of the Roman Empire, Cambridge.

Osgood, J. 20I4: Turia: A Roman Woman's Civil War, Oxford.

Osgood, J., Morrell, K. and Welch, K. (eds) 2019: The Alternative Augustan Age, Oxford.

Panciera, S. (ed.) I982: Atti del Colloquio internazionale AIEGL su epigrafia e ordine senatorio. Roma, I4-20 maggio I98I, 2 vols, Rome.

Peachin, M. 2004: Frontinus and the Curae of the Curator Aquarum, Stuttgart.

Pettinger, A. 2019: 'Rebuilding Romulus' Senate', in Osgood, Morrell and Welch 2019, 46-62.

Raepsaet-Charlier, M.-T. I981: 'Clarissima Femina', Revue internationale des droits de l'antiquité 28, I89-2I2 (= M.-T. Raepsaet-Charlier, Clarissima Femina. Études d'histoire sociale des femmes de l'élite à Rome. Scripta varia, ed. A. Álvarez Melero, Brussels, 20I6, I-20).

Raepsaet-Charlier, M.-T. I983: 'A propos de Julia Soaemias, Aelia Gemellina et Vedia Phaedrina', Revue internationale des droits de l'antiquité 30, I $85-92$.

Raepsaet-Charlier, M.-T. I987: Prosopographie des femmes de l'ordre sénatorial (I ${ }^{\mathrm{er}}-I I^{\mathrm{e}}$ siècles), 2 vols, Louvain.

Rich, J. W. I990: Cassius Dio: The Augustan Settlement (Roman History 53.I-55.9), Warminster.

Richardson, J. S. 20I 2: Augustan Rome 44 BC to AD I4: The Restoration of the Republic and the Establishment of the Empire, Edinburgh.

Rilinger, R. I991: 'Ordo und dignitas als soziale Kategorien der römischen Republik', in M. Hettling, C. Huerkamp, P. Nolte and H.-W. Schmuhl (eds), Was ist Gesellschaftsgeschichte? Positionen, Themen, Analysen. Hans-Ulrich Webler zum 60. Geburtstag, Munich, 8I-90 (= R. Rilinger, Ordo und dignitas. Beiträge zur römischen Verfassungs- und Sozialgeschichte, ed. T. Schmitt and A. Winterling, Stuttgart 2007, 95-104).

Roller, M. B. 200I: Constructing Autocracy: Aristocrats and Emperors in Julio-Claudian Rome, Princeton, NJ.

Ruggiero, I. 20I7: Ricerche sulle Pauli Sententiae, Milan.

Russell, A. 20I9: 'Inventing the imperial Senate', in Osgood, Morrell and Welch 2019, 324-42.

Rüpke, J. 2006: 'Religion in the lex Ursonensis', in C. Ando and J. Rüpke (eds), Religion and Law in Classical and Christian Rome, Stuttgart, 34-46.

Saller, R. P. I982: Personal Patronage under the Early Empire, Cambridge.

Saller, R. P. 1994: Patriarchy, Property and Death in the Roman Family, Cambridge.

Santangelo, F. 20I2: 'Senate, Roman Republic and Empire', Encyclopedia of Ancient History II.6I $40-4$. 
Scheid, J. I990: Romulus et ses frères. Le collège des frères arvales, modèle du culte public dans la Rome des empereurs, Bibliothèque des Écoles françaises d'Athènes et de Rome 275, Rome.

Scheidel, W. 20I5: 'State revenue and expenditure in the Han and Roman Empires', in W. Scheidel (ed.), State Power in Ancient China and Rome, New York, I 50-80.

Scheidel, W. 20I7: The Great Leveler: Violence and the History of Inequality from the Stone Age to the Twenty-First Century, Princeton, NJ.

Sherwin-White, A. N. I973: The Roman Citizenship, and edn, Oxford.

Spalthoff, B. H. 20I0: Repräsentationsformen des römischen Ritterstandes, Tübinger Archäologische Forschungen 7, Rahden.

Spawforth, A. J. S. I98 5: 'Families at Roman Sparta and Epidaurus: some prosopographical notes', The Annual of the British School at Athens 80, I9I-258.

Stein, A. I9I 2: 'Griechische Rangtitel in der römischen Kaiserzeit', Wiener Studien 34, I60-70.

Steiner, A. P. 1973: 'The vigintivirate during the Empire: a study of the epigraphical evidence', unpublished Ph.D. thesis, Ohio State University.

Stelluti, N. 1997: Epigrafi di Larino e della bassa Frentania, 2 vols, Campobasso.

Syme, R. I939: The Roman Revolution, Oxford.

Syme, R. I958: Tacitus, 2 vols, Oxford.

Talbert, R. J. A. I984: The Senate of Imperial Rome, Princeton, NJ.

Talbert, R. J. A. I996: 'The Senate and senatorial and equestrian posts', in A. K. Bowman, E. Champlin and A. W. Lintott (eds), The Cambridge Ancient History, Vol. ro: The Augustan Empire, 43 B.C.-A.D 69, 2nd edn, Cambridge, 324-43.

Thomas, Y. I982: 'Droit domestique et droit politique à Rome. Remarques sur le pécule et les honores des fils de famille', Mélanges de l'École française de Rome - Antiquité 94, 527-80.

Thomas, Y. 2007: 'L'enfant à naître et l' "héritier sien": sujet de pouvoir et sujet de vie en droit romain', Annales: Histoire, Sciences Sociales 62, 29-68.

Veyne, P. I976: Le pain et le cirque. Sociologie historique d'un pluralisme politique, Paris.

Wallace-Hadrill, A. I98 I: 'Family and inheritance in the Augustan marriage laws', Proceedings of the Cambridge Philological Society 27, 58-80 (= J. Edmondson (ed.), Augustus, Edinburgh, 2009, 250-74).

Wallace-Hadrill, A. I982: 'The Golden Age and sin in Augustan ideology', Past \& Present 95, I9-36.

Watson, A. I998: The Digest of Justinian, 4 vols, 2nd edn, Philadelphia, PA.

Weinstock, S. I937: 'Römische Reiterparade', Studi e Materiali di Storia delle Religioni I3, Io-24.

Williamson, C. 2005: The Laws of the Roman People: Public Law in the Expansion and Decline of the Roman Republic, Ann Arbor, MI.

Winterling, A. I999: Aula Caesaris. Studien zur Institutionalisierung des römischen Kaiserhofes in der Zeit von Augustus bis Commodus (3 I v.Chr.-I 92 n.Chr.), Munich.

Winterling, A. 20Ir: Caligula: A Biography, trans. D. L. Schneider, G. Most and P. Psoinos, Berkeley, CA (first published as Caligula: Eine Biographie, Munich, 2003).

Wiseman, T. P. I97I: New Men in the Roman Senate, I39 B.C.-A.D. I4, Oxford.

Woodman, A. J. 2017: The Annals of Tacitus, Books 5 and 6: Edited with a Commentary, Cambridge.

Woodman, A. J. and R. H. Martin I996: The Annals of Tacitus, Book 3: Edited with a Commentary, Cambridge. 